\title{
Who Signs up for E-Verify? Insights from DHS Enrollment Records
}

Pia Orrenius, Madeline Zavodny and Sarah Greer

Forthcoming in: Orrenius, Pia M., Zavodny, M. \& Greer, S. (2020), "Who Signs up for E-Verify? Insights from DHS Enrollment Records." International Migration Review.

\section{Working Paper 2002}

Research Department

https://doi.org/10.24149/wp2002

Working papers from the Federal Reserve Bank of Dallas are preliminary drafts circulated for professional comment. The views in this paper are those of the authors and do not necessarily reflect the views of the Federal Reserve Bank of Dallas or the Federal Reserve System. Any errors or omissions are the responsibility of the authors. 


\title{
Who Signs up for E-Verify? Insights from DHS Enrollment Records*
}

\author{
Pia M. Orrenius ${ }^{\dagger}$, Madeline Zavodny ${ }^{\ddagger}$ and Sarah Greer ${ }^{\S}$
}

January 2020

\begin{abstract}
E-Verify is a federal electronic verification system that allows employers to check whether their newly hired workers are authorized to work in the United States. To use E-Verify, firms first must enroll with the Department of Homeland Security (DHS). Participation is voluntary for most private-sector employers in the United States, but eight states currently require all or most employers to use E-Verify. This article uses confidential data from DHS to examine patterns of employer enrollment in E-Verify. The results indicate that employers are much more likely to sign up in mandatory E-Verify states than in states without such mandates, but enrollment is still below 50 percent in states that require its use. Large employers are far more likely to sign up than small employers. In addition, employers are more likely to newly enroll in E-Verify when a state's unemployment rate or population share of likely unauthorized immigrants rises. However, enrollment rates are lower in industries with higher shares of unauthorized workers. Taken as a whole, the results suggest that enrolling in the program is costly for employers in terms of both compliance and difficulty in hiring workers. A strictly enforced nationwide mandate that all employers use an employment eligibility program like E-Verify would be incompatible with the current reliance on a large unauthorized workforce. Allowing more workers to enter legally or legalizing existing workers might be necessary before implementing E-Verify nationally.
\end{abstract}

Keywords: Illegal immigration, unauthorized workers, E-Verify, worksite enforcement, immigration policy

JEL codes: J15, J61, L20

\footnotetext{
*We thank Rene Flores and session participants at the 2018 Population Association of America meeting and the anonymous reviewers for helpful comments and Alexander Abraham for excellent research assistance. The views expressed here are solely those of the authors and do not reflect those of the Federal Reserve Bank of Dallas or the Federal Reserve System. $\dagger^{\dagger}$ Pia M. Orrenius, Federal Reserve Bank of Dallas and IZA, pia.orrenius@dal.frb.org.

$\ddagger_{\text {Madeline Zavodny, University of North Florida and IZA, m.zavodny@unf.edu. }}$

$\S$ Sarah Greer, Associa.
} 


\section{Introduction}

E-Verify is a federal system that enables employers to electronically confirm whether new hires are legally eligible to work in the United States. ${ }^{1}$ The system is intended to deter the hiring of unauthorized immigrants. As of October 2019, some or all employers were required to use EVerify in 22 US states. ${ }^{2}$ About half of all new hires in the United States are now vetted through E-Verify, and over 600,000 employers have enrolled in the program since 2004 (Orrenius and Zavodny 2017). Despite this widespread use, little is known about when and why employers decide to use the E-Verify system. This article aims to help fill that void by examining determinants of the state-level number and share of employers enrolled in the program and focusing on the effect of state laws that require employers to use it. Employer enrollment in EVerify is an important topic, given the calls by many US politicians, including President Donald Trump, for a nationwide E-Verify requirement to reduce unauthorized immigration.

A growing body of research examines the impact of state E-Verify requirements on unauthorized and legal workers. Studies typically conclude that fewer unauthorized immigrants live and work in a state after it requires employers to use E-Verify (Bohn et al. 2014; AmuedoDorantes and Lozano 2015; Orrenius and Zavodny 2016). There is some evidence that the impact varies across states, although why the impact varies is unknown (Orrenius and Zavodny 2017). Further, some unauthorized immigrants who remain in states that require employers to use E-Verify shift from formal wage-and-salary employment to self-employment to evade E-

\footnotetext{
${ }^{1}$ The E-Verify website is https://www.e-verify.gov/ (accessed October 20, 2019). For background on the program and US employment eligibility verification programs, see Bruno (2018).

${ }^{2}$ See https://www.efficienthire.com/do-you-know-the-list-of-states-that-require-e-verify/ (accessed October 21, 2019).
} 
Verify (Bohn and Lofstrom 2013). This shift increases the size of the informal sector and may reduce tax collections, among other policy implications. When states begin to require E-Verify use, unauthorized immigrants have more difficulty switching employers since all new hires in those states must be screened by E-Verify (Orrenius and Zavodny 2015). This inability to switch employers reduces those workers' potential upward mobility and makes them more vulnerable to employer exploitation, including lower wages. However, the evidence is mixed as to whether average wages fall among unauthorized immigrants who remain employed in states that mandate E-Verify (Amuedo-Dorantes and Bansak 2012; Amuedo-Dorantes and Bansak 2014; Orrenius and Zavodny 2015). It is also unclear whether E-Verify mandates benefit authorized workers, an ancillary effect often promoted by the program's supporters. ${ }^{3}$ Studies of effects on legal immigrants' and US natives' employment and wages reach mixed conclusions (AmuedoDorantes and Bansak 2014; Bohn et al. 2015; Orrenius and Zavodny 2015).

An important caveat to the results noted above is that studies of the effects of state EVerify requirements do not necessarily measure the program's impact since they are unable to measure program use. Studies of state mandates implicitly assume that at least some employers began using the system when required to do so, but researchers do not know the actual extent of E-Verify use before and after a requirement went into effect. Thus, we do not know whether estimates of a law's impact capture the program's actual impact. For example, if many employers were already using E-Verify before states began requiring its use, studies may underestimate the program's impact. Further, many of the studies noted above use a difference-

\footnotetext{
${ }^{3}$ For example, a US Citizenship and Immigration Services (USCIS) website promoting the Buy American and Hire American executive order states, "To help reduce illegal immigration and preserve jobs for U.S. workers, USCIS encourages all U.S. employers to verify the employment eligibility of all new hires through E-Verify." https://www.uscis.gov/legal-resources/buy-american-hire-american-putting-american-workers-first (accessed October 20, 2019].
} 
in-differences technique that compares changes in one or more states that implemented an EVerify requirement with changes in states that did not. Some employers in comparison states, however, may have begun using E-Verify at the same time, perhaps because multistate employers have uniform human-resource practices across states or because other changes that happened to coincide with the timing of a law prompted employers in multiple states to enroll in E-Verify. This possibility makes it difficult to assess the effect of such laws using a differencein-differences technique or even to know whether the technique under- or over-estimates the effect.

A final complication for most studies is that some of the state laws mandating E-Verify contained additional anti-unauthorized immigrant provisions or were followed by other antiunauthorized immigrant laws. Alabama and Georgia are examples of the former, while Arizona is an example of the latter. This situation again makes it difficult to know whether to attribute any observed changes to the E-Verify requirement. Knowing the extent and determinants of EVerify enrollment or use within states over time may help with interpreting observed changes after states impose an E-Verify requirement. It also may help researchers and policy-makers forecast compliance with a nationwide requirement and its possible effects on unauthorized and legal workers.

Only one previous study systematically examines employer participation in E-Verify. Bachmeier et al. (2012) examine data from the US Department of Homeland Security (DHS) on the number of times the E-Verify system was used to check new hires' eligibility from 2005 to 2009. They find that E-Verify usage increased markedly over that period, rising from about 1 percent of new hires checked against the system in 2005 to 10 percent in 2009. The increase was much larger in states that began requiring some or all employers to use E-Verify. However, they 
find that usage rates remained well below 100 percent, even in the two states that implemented universal requirements during that period, Arizona and Mississippi. Subsequent calculations using DHS data for the period July 2016 to June 2017 reveal considerable variation in usage rates across states, with screening rates relative to new hires typically— but not always—-higher in states with a universal mandate than in other states (Henderson 2018).

We build on this earlier work by examining employer enrollment in the E-Verify program from 2004 to 2015. During this period, seven states implemented a universal E-Verify requirement, and several other states began requiring government agencies or contractors to use it. Using confidential DHS data, we investigate enrollment patterns over time by state, employer size, and industry. Although enrollment does not necessarily measure employer use, enrolling in the program is a necessary precondition for employers to use the system and is likely a good proxy for actual use. We find that enrollment increases considerably when a state passes an EVerify law, particularly a universal mandate that applies to all employers in that state. However, enrollment rates remain well below 100 percent even years after a universal mandate went into effect. We find that some employers enroll in states where E-Verify is voluntary, although enrollment rates are typically lower than in states requiring it. In general, large employers are far more likely to enroll in E-Verify than small employers, while employers in industries with a high dependence on unauthorized workers are less likely to enroll. Our results also suggest that employers are less likely to enroll in E-Verify when the unemployment rate falls within a state, suggesting that labor market tightness influences how thoroughly employers screen for unauthorized workers.

Our results have two major implications. First, they suggest that widespread use of employment eligibility verification programs like E-Verify is largely incompatible with the 
presence of a large unauthorized workforce, as in the United States. To effectively implement EVerify nationally while limiting direct and indirect costs and other unintended consequences, it would likely be necessary to legalize existing workers or, at a minimum, to admit more foreign workers legally. Second, the results point to limitations of studies that compare states that have enacted E-Verify requirements with states that have not. Although enrollment rates are higher in states that mandate E-Verify, some employers enroll in it in other states as well. This enrollment pattern makes it difficult to extrapolate from those studies what the effects of a nationwide EVerify requirement would be on unauthorized immigrants or legal workers.

The next section provides more background about the E-Verify program and the state laws on which this article focuses. The article then describes the data and methods used to examine employer enrollment in the program, followed by the results, which provide the first systematic examination of patterns of employer enrollment in E-Verify. The article concludes with a discussion of the implications of those results for researchers and policy-makers.

\section{Background on the E-Verify Program and State Mandates}

E-Verify is a free, web-based system operated by DHS's U.S. Citizenship and Immigration Services division. It allows businesses to check employee eligibility to legally work in the United States by comparing information provided by a new hire with federal records. The 1986 Immigration Reform and Control Act (IRCA) made it illegal to knowingly employ people who are not allowed to work in the United States and required that employers review eligibility documents for all new hires (Bruno 2018). Post-IRCA, newly hired workers must show their employer documents that indicate their eligibility to work. To address concerns about widespread availability and use of fraudulent eligibility documents, in 1996 the US Congress 
mandated the creation of a system to authenticate applicant-provided documents. E-Verify's precursor, the Basic Pilot program, became available in 1997 to employers in five states with large immigrant populations: California, Florida, Illinois, New York, and Texas (Bruno 2018). It became available nationwide in 2004 and was renamed E-Verify in 2007 (Bruno 2018).

The E-Verify system compares information from the documents that newly hired workers present to their employers with federal government records. All employers, regardless of whether they use E-Verify, are required to complete and retain a form, called Form I-9, for each new hire using information from a list of acceptable documents presented by the employee, such as a passport, permanent resident card, driver's license, or employment authorization document. Employers that use E-Verify enter information from the Form I-9 into the online system. Employers are legally only allowed to do so after a job offer is accepted; they are not allowed to use E-Verify to pre-screen applicants because of concerns about potential discrimination against minorities (Bruno 2018). E-Verify compares the entered information with Social Security Administration and, if needed, DHS records and then notifies the employer as to whether the information matches that of an eligible worker. Employers are required to inform workers whose information does not match and to give them eight federal workdays to resolve the discrepancy before terminating their employment.

The US federal government has used E-Verify to check its employees' work eligibility since 2007 and has required certain contractors to do so since regulations put in place in 2008 and 2009 (Bruno 2018). States and localities have authority to regulate the use of E-Verify by all other public and private employers. Since the mid-2000s, a total of 23 states have required some or all employers to use E-Verify (Figure 1). Most of those states have requirements that apply only to the public sector and/or government contractors, but eight had a universal mandate in 
place as of 2019. ${ }^{4}$ In several of those eight states (namely, Georgia, North Carolina, South Carolina, and Utah), the universal mandate was preceded by a mandate that applied just to the public sector and/or government contractors. The universal mandates in Alabama, Georgia, Mississippi, and North Carolina were phased in by employer size or sector, and the mandates in Georgia, North Carolina, Tennessee, and Utah permanently exempt small employers. Two states (Minnesota and Rhode Island) have rescinded their requirement or let it lapse partially or completely.

\section{Data}

This article uses confidential E-Verify data provided by DHS to the authors upon request. The data are based on memorandums of understanding (MOUs) signed by employers when they joined the E-Verify program. The MOU stipulates, among other things, that the employer will use E-Verify for all new hires while the MOU is in effect. ${ }^{5}$ For employers with five or more employees, the dataset provided by DHS includes the employer's name; employer ID number (EIN); number of employees in numeric intervals; the employer's industry by 3-digit NAICS (North American Industry Classification System) code; the city, state and zip code of the office that signed the MOU; the date the MOU was signed; and the number of hiring sites and the states where those hiring sites are located. For employers with fewer than five employees, DHS

\footnotetext{
${ }^{4} \mathrm{~A}$ few states have or had laws that give employers an alternative to using E-Verify, such as requiring hires to show a valid driver's license. We do not classify those states as mandatory E-Verify states. Details on state laws, including size phase-ins and when laws were adopted and became effective, as of 2017 are available in Orrenius and Zavodny (2017).

5 "The Employer agrees to create an E-Verify case for new employees within three Employer business days after each employee has been hired (after both Sections 1 and 2 of Form I-9 have been completed), and to complete as many steps of the E-Verify process as are necessary according to the E-Verify User Manual." (Page 3 of https://www.e-verify.gov/sites/default/files/everify/memos/MOUforEVerifyEmployer.pdf (accessed October 20, 2019)).
} 
provided data aggregated to the zip-code level. For each zip code, we know only how many MOUs were signed by small employers in each month and year. ${ }^{6}$

We aggregate the data into the number of employers that signed an MOU in each quarter by state. Employers with more than five employees are counted in each state in which they indicated a hiring site, in addition to the state of the office that signed the MOU. The data begin in the first quarter of 2004, soon after the program became available nationwide, and go through the third quarter of 2015. We create a count of the number of employers that signed up in a given quarter and a count of the cumulative number of employers that had signed up since 2004 in each state. We examine the data at the state level since we are particularly interested in the effect of state laws requiring employers to use E-Verify. Some counties and cities also require E-Verify use, but there appear to be relatively few such requirements that apply to all employers within a locality. $^{7}$

The share of employers that enrolled in E-Verify is likely more relevant than the count of employers that enrolled. To create the share of employers that enrolled in E-Verify, we divide the counts we created from the DHS data by the total number of establishments in the state during a given quarter. The total number of establishments is from the Quarterly Census of Employment and Wages (QCEW). It bears noting that these shares are imperfect measures since the DHS data are a mix of establishments and firms. Nonetheless, they are likely a good proxy for the share of employers enrolling in E-Verify and are the best (and only) available data on enrollment. Another cautionary note is that our data are enrollment in E-Verify, not actual use;

\footnotetext{
${ }^{6}$ The data have multiple MOUs for some EINs and employer names. If more than one MOU is reported for a given employer in the same zip code, we keep only the earliest one. In the small employer dataset, we drop any repeat observations for the same zip code and month.

${ }^{7}$ According to Orrenius and Zavodny (2017), at least 19 counties and cities have enacted E-Verify laws that cover some or all workers. Many of those are in states with an E-Verify requirement. Pham and Van (2014) discuss local policies in more detail.
} 
we requested usage data as well but were only able to obtain enrollment data. ${ }^{8}$ Bachmeier et al. (2012), in contrast, examine usage data for the report they submitted to DHS and were able to make publicly available (although their data are likewise confidential). ${ }^{9}$

\section{E-Verify Participation and State Mandates}

As discussed earlier, studies of the effects of state E-Verify laws implicitly assume that employers are complying with the law. However, the extent of compliance is unknown. There are several reasons not to expect 100-percent compliance with an E-Verify mandate. E-Verify may make it more difficult and time consuming for employers to hire workers if it deters potential applicants from seeking employment with firms that participate in the system. ${ }^{10}$ Additionally, although E-Verify is free to use, it creates an administrative burden for employers, who must take the time to enter the information into the system and then deal with any nonconfirmations. The penalty for non-compliance is substantial in most states-typically, the business's license is revoked, but the likelihood of being caught is low. Employers, therefore, may opt not to enroll even if they know they are required to use the system. Employers who typically do not hire immigrants may be particularly reluctant to sign up. Employers may also delay signing up until they hire an employee, which, for smaller firms, may not occur for quite a while after an E-Verify requirement goes into effect.

\footnotetext{
${ }^{8}$ Our measure of the share of employers that enroll in E-Verify (the count of employers enrolled divided by the number of establishments) is probably smaller than the share of hires run through the system since large employers are more likely than small employers to participate in E-Verify and since most employers are small.

${ }^{9}$ One potential complication of employer usage data is that queries may not originate from the state in which an employer is located. For multistate firms, all queries might come from headquarters, for example. In addition, some employers outsource their E-Verify queries to firms that specialize in such human resources-related tasks ("E-Verify employer agents"). Our data should avoid such concerns, although they raise other ones.

${ }^{10}$ The MOU requires that employers post a visible notice at their place of business. In addition, a list of employers with five or more employees enrolled in the program is available online at https:/www.e-verify.gov/about-everify/e-verify-data/participating-employers (accessed October 20, 2019).
} 
Meanwhile, some employers may opt to use E-Verify in states that do not require them to do so. Employers may choose to participate because they want a more reliable way to screen their new workers and believe the benefits of such screening outweigh the costs. Firms that operate in more than one state may use E-Verify in all establishments for uniformity. In addition, using E-Verify may serve as an affirmative defense against charges of knowingly hiring unauthorized workers. This potential defense may spur employers to enroll in and use the program.

Employer enrollment in E-Verify increases noticeably when states require all employers to use it, but compliance appears to be incomplete. Figure 2 shows the cumulative number of employers that have enrolled in E-Verify as a share of all establishments in each of the seven states that enacted a universal mandate before 2015. The figure also shows the average share of employers enrolled in E-Verify each year in states that implemented a non-universal E-Verify requirement (but did not implement a universal requirement) at some point between 2004 and 2015 and in states that did not implement any E-Verify requirement during that period. The legend lists the states shown in the figure in descending order by the last data point shown; Alabama has the highest share of employers enrolled in E-Verify in 2015, and states with no EVerify law have the lowest share. (The online appendix shows the cumulative share of employers enrolled for each state and indicates when E-Verify requirements went into effect.)

Figure 2 indicates that Arizona, Alabama, and South Carolina all experienced sharp increases in enrollment around the time their law was adopted or went into effect and a more gradual increase thereafter. ${ }^{11}$ Notably, the E-Verify laws in those states went into effect for all

\footnotetext{
${ }^{11}$ Arizona's law was adopted in July 2007 and went into effect in January 2008. Alabama's law was adopted in June 2011 and went into effect for government contractors in January 2012 and for all employers in April 2012. South Carolina adopted a requirement for public employers in June 2008 that went into effect in January 2009 and a requirement for all employers in June 2011 that went into effect in January 2012.
} 
employers at once. In three of the other states - Georgia, Mississippi, and North Carolina - the laws were phased in by employer size. Therefore, it makes sense that the increase in the enrollment share is more gradual in those states. Utah is the exception to this pattern. That state's law was adopted in March 2010 and went into effect in July 2010 for all employers with 15 or more employees. Although there is an increase in the share of employers enrolled that coincides with that timing, it is smaller than in the other states without a phase-in period.

Enrollment shares vary considerably across the seven states with universal mandates. Although the share is higher in all seven states than in the two comparison groups, it varies from around 40 percent in Alabama and Arizona in late 2015 to only 10 percent in North Carolina. North Carolina may have the lowest share because, among the states included in Figure 2, it exempts the most employers from the program. North Carolina exempts employers with fewer than 25 employees, whereas Georgia exempts those with 10 or fewer and Utah those with fewer than $15 .^{12}$ The other states do not have a size exemption. The size exemption may play a big role in enrollment shares since most employers are small. In the national QCEW data, about 62 percent of establishments have fewer than five employees, 26 percent have between five and 19, and 10 percent have between 20 and 99. Only 2 percent of establishments have over 100 employees. $^{13}$

As Figure 2 indicates, enrollment shares are higher in states that require some or all public-sector employers or government contractors to use E-Verify than in states that have no EVerify requirement. Figure 3 shows the cumulative enrollment share in each state that enacted a non-universal E-Verify requirement from 2004 to 2015 (Rhode Island is not shown because its

\footnotetext{
12 Tennessee's law provides an alternative (keeping a copy of Form I-9, in essence) for employers with fewer than 50 employees but did not go into effect until 2017.

${ }^{13}$ The distribution of establishments by size in the mandatory E-Verify states is similar to the national distribution.
} 
requirement was rescinded). There is considerable diversity in enrollment shares across states.

Since the denominator is all establishments, we would not expect these shares to reach as high as those in the universal mandate states shown in Figure 2. Therefore, it is surprising that the enrollment share in Missouri is above 25 percent by late 2015, well above the shares in three of the universal mandate states. Why Missouri's enrollment share is so high is not clear since its EVerify law applies only to public employers and government contractors. ${ }^{14}$ There is a clearer explanation for the states with the lowest shares - the laws in Pennsylvania and West Virginia apply only to public-works contractors and new hires in the capitol complex, respectively.

Enrollment in E-Verify may vary by industry. Industries with disproportionately more small employers would be expected to have lower enrollment shares, especially in universalmandate states with employer size exemptions, while industries with many government contractors would be expected to have relatively high enrollment shares. Industries that depend relatively heavily on unauthorized immigrants might be expected to have high enrollment shares if employers rely on E-Verify to root out ineligible workers and deter others from applying. Alternatively, employers in those industries might not want to use E-Verify because then they are legally required to dismiss workers identified as ineligible. Using E-Verify also might make finding qualified workers more difficult, particularly in tight labor markets and in industries that traditionally rely on undocumented workers.

Bachmeier et al. (2012) find that employer use of E-Verify from 2005 to 2009 was higher and rose more in industries with relatively few low-skilled foreign-born workers. Our data on enrollment rates by industry, shown in Figure 4, are somewhat consistent with this finding. Two of the industries with relatively high enrollment rates - utilities and transportation and

\footnotetext{
${ }^{14}$ The regression results are robust to excluding Missouri from the sample.
} 
warehousing — have relatively low shares of workers who are unauthorized immigrants (Passel and Cohn 2015). Utilities, of course, are a heavily regulated sector with a large share of publicly owned firms, so it is no surprise that the E-Verify enrollment rate is highest in that industry. Manufacturing may have a relatively high enrollment rate because of government contracts. Industries with relatively high shares of workers who are unauthorized immigrantsconstruction, accommodation and food services, and agriculture - tend to be in the middle in terms of enrollment rates. ${ }^{15}$

\section{Methods}

Next, we examine the effect of E-Verify laws on E-Verify enrollment rates, using ordinary least squares (OLS) regression models of the basic form

E-V Enrollment st $=\alpha+\beta_{1}$ E-Verify $_{\mathrm{st}}+\beta_{2}$ Economic Conditions $_{\mathrm{st}-1}+\beta_{3}$ Immigration Policy $_{\mathrm{st}}$ (1)

$$
+ \text { State }_{\mathrm{s}}+\text { Time }_{\mathrm{t}}+\text { Trend }_{\mathrm{st}}+\varepsilon_{\mathrm{st}}
$$

where $s$ indexes states and $t$ indexes time. The dependent variable, $E$ - $V$ Enrollment, is one of three measures: the natural log of the number of employers newly enrolling in E-Verify; the share of employers newly enrolling in E-Verify; or the cumulative share of employers enrolled in E-Verify in a given state and quarter. We examine three measures of employer enrollment in the program since we lack a perfect measure of employer participation in the program. The first two measures reflect flows into the system, while the third measure is the stock of employers signed up for the system.

\footnotetext{
${ }^{15}$ According to Passel and Cohn (2015), the share of workers who are unauthorized immigrants by industry is as follows for the year 2012: agriculture, 16 percent; construction, 12 percent; manufacturing, 6 percent; transportation and utilities, 3 percent; and leisure and hospitality, 9 percent.
} 
E-Verify is a dummy variable indicating whether a state requires employers to use EVerify. In some specifications, the variable indicates whether a requirement has been adopted, while in others it indicates whether a requirement is in effect. We include separate variables for mandates that apply to all employers, mandates that apply to the public sector, and mandates that apply to government contractors. When we examine a flow measure of E-Verify enrollment, the estimated coefficient on an E-Verify law gives the average effect of that law on the quarterly number or share of employers newly signing up for E-Verify. For the stock measure of E-Verify enrollment, the estimated coefficient gives the average effect over time of a state law requiring employers to use the system on the share of employers enrolled in the system.

Economic Conditions controls for business-cycle conditions and demographics that may affect an employer's willingness to sign up for E-Verify policies and the number of new employers. It includes five variables measuring business-cycle conditions: the state unemployment rate, real annual personal income per capita, real annual government expenditures per capita, single-family housing starts, and single-family construction permits. Demographics are measured using the population share of unauthorized immigrants as proxied by the population share of Hispanic immigrants who are not naturalized US citizens. These variables are lagged one year to avoid concerns that they are affected by enactment of an E-Verify policy, and all except the unemployment rate and Hispanic immigrant population share are measured in natural logs. ${ }^{16}$ Immigration Policy includes two other state-specific measures of immigration

\footnotetext{
${ }^{16}$ The unemployment rate is a monthly, seasonally adjusted series from the Bureau of Labor Statistics and was aggregated to a simple quarterly average. The government expenditures data are from the Census Bureau, deflated to 2014 dollars using the CPI-U, then divided by the annual population in each state to create real government expenditures per capita. Real per capita personal income by state is from the Bureau of Economic Analysis. Those data are quarterly and seasonally adjusted in chained 2009 dollars. Housing starts is a seasonally adjusted and annualized monthly series from the Bank of Tokyo-Mitsubishi UFJ. These data were also aggregated to a simple quarterly average. Housing permits by state is a monthly series from the Census Bureau. We seasonally adjusted the permits data and summed the monthly values to get quarterly data. The Hispanic immigrant population share is
} 
enforcement: a dummy variable indicating the presence of a $287(\mathrm{~g})$ agreement with the federal government and a dummy variable indicating the presence of Secure Communities in a state. ${ }^{17}$

The variables controlling for economic conditions and immigration policy are important since many E-Verify mandates coincided with the 2007-2009 recession and an increase in immigration enforcement. While these variables control for the effect of changes in state-level economic conditions and immigration policy, we do not control for any factors below the state level, such as local adoption of a $287(\mathrm{~g})$ agreement. We focus on interpreting the estimated coefficients of these variables in the regressions that examine flow measures of E-Verify enrollment since the flow measures, not the stock measure, should reflect the effect of changes in economic conditions and immigration policies. The estimated coefficients on these variables indicate how changes in business-cycle conditions, demographics, or immigration policy within a state are related to changes in the share of employers newly enrolling in E-Verify in that state. Importantly, due to the inclusion of state fixed effects, as explained below, the estimated coefficients are not identified from the relationship between the share of employers newly enrolling in E-Verify and the level of the unemployment rate (or the Hispanic immigrant population share) across states. Rather, the identification is based on the relationship between

created from 2000 Census and 2005-2014 American Community Survey data. Data for 2003 and 2004 are linearly interpolated from the 2000 and 2005 data, and annual values are used for all four quarters within a year.

${ }^{17}$ Under the $287(\mathrm{~g})$ program, state and local law enforcement enter into a partnership with US Immigration and Customs Enforcement (ICE) to perform the functions of federal immigration agents. The regressions include a variable indicating the fraction of the quarter that a state has a task-force enforcement model or a jail enforcement model in place. Under the task-force enforcement model, law enforcement officers may interrogate and arrest alleged noncitizens whom they believe to have violated federal immigration laws. Under the jail enforcement model, law enforcement officers may interrogate alleged noncitizens who have been arrested on state or local charges and may lodge immigration detainers on inmates thought to be subject to removal. The regressions also include a variable for the fraction of the quarter that a state implemented Secure Communities. Under Secure Communities, participating jails submit arrestees' fingerprints to immigration databases, giving ICE access to information on individuals held in jails. These variables remain equal to one after a state has initiated a $287(\mathrm{~g})$ program or Secure Communities. We thank Sarah Bohn for graciously providing the information on 287(g) laws. 
these variables within states - in effect, the regressions examine changes within states, not levels across states.

The regressions control for time-invariant state-specific factors with state fixed effects and for changes in the business cycle, seasonal factors, and immigration patterns that are shared by all states with quarter-by-year fixed effects. The regressions include state-specific linear time trends to control for underlying trends at the state level. Because the regressions include state fixed effects and state-specific time trends, the estimated coefficient on the E-Verify variable measures the average change in employer enrollment in E-Verify after an E-Verify requirement has been adopted or gone into effect, controlling for the linear trend in enrollment within each state and for economic conditions and other immigration policies. States that do not have an EVerify requirement do not contribute to the identification of the coefficient of an E-Verify requirement, but they do help identify the coefficients of the other variables and the time fixed effects. Observations are weighted using the number of establishments by state and quarter. The standard errors are clustered on the state in the regressions to control for state-specific heteroscedasticity. We estimate the regressions at the state level, instead of examining whether individual employers enroll in E-Verify, since we focus on the impact of state-level laws. ${ }^{18}$

Our empirical approach assumes that a state's decision to enact E-Verify requirements is not a function of employer enrollment in E-Verify. If states enact E-Verify mandates in response to concerns about low enrollment, then our estimates will be biased. However, this situation is unlikely since little information about E-Verify enrollment or usage is publicly available. States do appear to be more likely to enact E-Verify requirements and other immigration enforcement measures when their immigrant population increases, although it is worth noting that states with

\footnotetext{
${ }^{18}$ In addition, almost no control variables are available at the employer level, and we lack information about employers that do not participate in the program.
} 
high immigrant population shares, as opposed to high immigrant population growth rates, are typically not the ones that enacted E-Verify requirements. Previous research suggests that the growth of immigrant populations in new areas during the 1990s and 2000s prompted some of those areas to adopt laws aimed at discouraging immigrants from settling there (Boushey and Luedtke 2011; Newman et al. 2012; Monogan 2013; Ybarra, Sanchez, and Sanchez 2016). This fact motivates our controls for the lagged Hispanic immigrant population share and other immigration enforcement policies. Our regression model, which implicitly examines changes instead of levels, should capture any effect of an increasing Hispanic immigrant population share on employer enrollment in E-Verify.

Table 1 reports sample means for the three measures of employer enrollment in E-Verify and the main control variables included in the regressions. It shows means by type of E-Verify mandate in effect, in addition to the overall means. ${ }^{19}$ The first two measures of employer enrollment in E-Verify are the flow measures: the number or share of employers newly enrolling in E-Verify during a given quarter. Not surprisingly, the average number and share of employers enrolling in E-Verify are highest in states that have an E-Verify mandate in effect for all employers. The average number and share are about half as large if an E-Verify mandate is in effect for public-sector or government contractors and even lower if no E-Verify mandate is in effect. The third measure of employer enrollment in E-Verify is the stock measure-the share of employers that have enrolled in E-Verify in a state. Like the flow measures, this share is highest when there is a universal mandate, followed by a public-sector or government contractor mandate, and lowest when there is no mandate.

\footnotetext{
${ }^{19}$ Before a state has any law in effect, it is in the non-mandate column. Public-sector and government-contractor mandates are not mutually exclusive, so the number of observations by type of mandate sum to more than the total number of observations. States with a public-sector or contractor mandate followed by a universal mandate are no longer counted as having a public-sector or government contractor mandate after they have a universal mandate.
} 
The sample means of the control variables indicate that economic conditions tend to be worse in states with E-Verify mandates. This situation may reflect the fact that the requirements tended to be adopted during or soon after the 2007-2009 recession. Income and government spending are also lower, but these lower means may largely reflect the fact that many E-Verify states are in the South, a region that historically is poorer than the rest of the country. ${ }^{20}$ Southern states also tend to be newer immigrant destinations (e.g., Lichter and Johnson 2009), so they have lower Hispanic immigrant population shares. Lower Hispanic immigrant population shares in E-Verify states may also be partly due to an outflow of unauthorized immigrants and their families from those states after they enacted E-Verify mandates. States with E-Verify mandates are more likely to have 287(g) agreements and Secure Communities immigration enforcement measures in place as well. The prevalence of those agreements in E-Verify states partly reflects the fact that some E-Verify requirements were part of omnibus immigration laws, state laws that included several provisions targeting unauthorized immigrants. ${ }^{21}$ More generally, the pattern suggests that states that implemented E-Verify requirements enacted multiple anti-unauthorized immigrant measures or did so earlier than other states.

\section{Results}

Our results indicate that universal E-Verify mandates increase the number and share of employers enrolled in E-Verify. Table 2 reports regression results for the natural log of the number of employers newly enrolling in E-Verify. The estimates in the top row indicate that

\footnotetext{
${ }^{20}$ Relative income over time by US region is detailed here https://www.visualcapitalist.com/comparing-wealth-u-sgeographic-regions-time/ (accessed October 23, 2019).

${ }^{21}$ Good (2013) examines the effect of these omnibus immigration laws on the number of unauthorized immigrants. Alabama, Arizona, Georgia, Indiana, Missouri, Nebraska, Oklahoma, South Carolina, and Utah implemented omnibus immigration laws that included a work authorization provision.
} 
about 100 to 150 percent more employers enroll in E-Verify each quarter after a state adopted a universal E-Verify mandate, a sizable (and statistically significant) effect. Much of this enrollment appears to have occurred after a mandate was adopted but before it was actually in effect. The estimates in panel B, which look at the average change after a mandate went into effect rather than after it was adopted, indicate that about 50 to 90 percent more employers enrolled per quarter after a universal mandate went into effect. Those estimates are smaller than the corresponding estimates in panel A. Public-sector mandates and state-contractor mandates also increased the number of firms enrolling in E-Verify, but the effects are considerably smaller than for universal mandates and not statistically significant in the case of public-sector mandates in effect.

Table 3 shows regression results for the share of employers newly enrolling in E-Verify during a quarter. As with the number of employers, the share of employers enrolling was higher after a state adopted a universal E-Verify mandate. The results indicate that the share of employers enrolling was about 1.2 to 1.5 percentage points higher per quarter after a state adopted a universal mandate. The results again indicate that employers responded more after a law was adopted than after it went into effect and that universal mandates had a bigger impact than partial mandates. The E-Verify estimates are smaller, and not always statistically significant, for public-sector and government-contractor mandates than for universal mandates.

Tables 2 and 3 also report the estimated coefficients of two control variables: the unemployment rate and the Hispanic immigrant population share. The coefficients of the other variables controlling for economic conditions or immigration policy tend to be statistically insignificant and, therefore, are not shown here (but are available upon request). The results suggest that more employers enrolled in E-Verify when the unemployment rate rose in a state 
and that the share of employers enrolling in E-Verify increased as the Hispanic immigrant population share rose in a state. The unemployment rate result is consistent with employers being more reluctant to use E-Verify when labor markets were tight and workers were harder to find. The positive coefficients on the unemployment rate are particularly striking, given that fewer new establishments form when the unemployment is higher. Hence, we would expect fewer new enrollments when the unemployment rate is higher, all else equal. The Hispanic immigrant population share result suggests that employers were more concerned with avoiding hiring unauthorized workers as their population share rose. ${ }^{22}$ This result is consistent with the possibility that some employers enrolled in (and used) E-Verify to have an affirmative defense if audited by DHS for hiring unauthorized workers.

Universal mandates raised the share of employers enrolled in E-Verify by some 6 to 10 percentage points, according to the regressions examining the stock measure. As the top row of Table 4 shows, the share of employers enrolled in E-Verify was about 6 to 7 percentage points higher, on average, after a state adopted a universal E-Verify mandate. The results in panel B indicate that the share was about 10 percentage points higher after a universal mandate was in effect. The effects would be larger-about 14 percentage points for adopted laws and 16 percentage points for implemented laws - if the regressions did not control for state-specific linear trends, which absorb much of the post-requirement increase in E-Verify enrollment in those states. The finding that adoption of a universal mandate had a smaller effect than did implementation makes sense when looking at stocks. Although there was an initial surge of employers enrolling when a requirement was adopted, the number continued to rise over time, as Figure 1 indicates. Therefore, the stock of employers enrolled was higher when looking only

\footnotetext{
${ }^{22}$ A similar positive result holds if we use the foreign-born population share, the Hispanic population share, or the recent immigrant population share.
} 
after a law went into effect than after it was adopted. Meanwhile, adopted or implemented mandates that applied only to public-sector or government contractors did not significantly raise the share of employers enrolled in E-Verify. ${ }^{23}$

Tables 5 and 6 examine new enrollment shares and cumulative enrollment shares, respectively, by employer size. ${ }^{24}$ Large employers may be more likely to enroll in E-Verify since they hire workers more often, and many have human resources and legal departments that should be aware of state E-Verify requirements and are more able to take on the extra work. Large firms also may perceive more benefits from using E-Verify than small employers do. Large employers may be more likely to view using E-Verify as a way to avoid I-9 audits and raids by immigration enforcement agents, for which they may be targeted more often than are small employers. On the other hand, larger employers may be more likely to have establishments in multiple states. If they enroll in E-Verify at the same time in all states in which they operate, the regressions may show that state E-Verify requirements had less impact on larger firms than on smaller ones.

The E-Verify new enrollment rate increased considerably more among larger employers than among smaller ones after states adopted E-Verify laws, as panel A of Table 5 shows. The average increase in the share of employers with 500 or more employees enrolling in E-Verify in a state that adopted a universal mandate was almost 20 times larger than the average increase among employers with fewer than 5 employees. The increase in the share of employers newly enrolling in E-Verify rose monotonically across size categories in response to the adoption of universal and public-sector mandates, as the top two rows of Table 5 indicate. However,

\footnotetext{
${ }^{23}$ We do not report the estimated coefficients for the unemployment rate and Hispanic immigrant population share variables or other controls when the dependent variable is the stock measure since they do not have a clear interpretation, but the regressions include the same control variables throughout.

${ }^{24}$ The number of employers by state and size category used to create the denominators for the enrollment shares is only available for private-sector employers in the QCEW, so the denominators undercount the number of employers. The number of employers by state and size category is only available for the first quarter of each year, so values for the other quarters are linearly interpolated.
} 
adoption of a government-contractor mandate did not have a significant impact in any size category. Table 6 shows a similar result for the cumulative share of employers enrolled in EVerify: a universal mandate raised the share of employers enrolled across all size categories, but the effect's magnitude increased monotonically with size. Public-sector mandates also raised the cumulative share of larger employers enrolled in E-Verify, while government-contractor mandates did not have a significant effect in any size category. The pattern of the results for cumulative enrollment rates, shown in Table 6 , is similar for adoption versus implementation of an E-Verify requirement.

Perhaps surprisingly, panel B of Table 5 indicates that having a universal mandate in effect was negatively related to the new enrollment share among the largest employers. The difference between the results in panels A and B of Table 5 for large employers suggests that they enrolled in E-Verify soon after a universal or public-sector mandate was adopted instead of waiting until it went into effect. By the time the mandate went into effect, new enrollment shares were unaffected or even dropped for large firms since many of those who were going to enroll had already done so. The share of the largest employers newly enrolling in E-Verify increased after a government-contractor mandate went into effect, the only size category to show a significant effect of those laws.

The estimated coefficients of the unemployment rate variable suggest that larger employers' willingness to enroll in E-Verify was more sensitive to the business cycle. The estimated coefficients of the unemployment rate variable increased monotonically across size categories in both panels of Table 5. Further, enrollment shares among small employers- those with fewer than 5 employees or 5 to 19 employees - were not significantly related to the unemployment rate. The estimated coefficients of the Hispanic immigrant population share 
variable also appear to increase with employer size, but they show the opposite pattern in terms of statistical significance. Enrollment shares rose among small employers as the Hispanic immigrant population share increased, whereas enrollment shares among large employers did not change significantly when the Hispanic immigrant population share changed within a state (although the coefficients' magnitudes suggest a larger impact).

Lastly, Tables 7 and 8 report results for several industries that may be of particular interest given the patterns in Figure $4 .^{25}$ The first three industries shown in those tablesagriculture, forestry, fishing, and hunting; construction; and accommodations and food services - have relatively high fractions of workers who are unauthorized immigrants. The other two industries - manufacturing and utilities - have a medium fraction and a very low fraction, respectively, of workers who are unauthorized immigrants. The results suggest that industries with high fractions of unauthorized workers had smaller increases in their E-Verify enrollment rates in response to E-Verify mandates. In panel A of Table 7 and both panels of Table 8, the estimated coefficients of the universal and public-sector E-Verify variables are larger for manufacturing and utilities employers than for the other industries examined, although not all the differences are statistically significant. The difference in the results for utilities between panels A and B of Table 7 suggest that utilities enrolled in E-Verify soon after a universal or public-sector mandate was adopted, instead of waiting until it went into effect. Utilities were the only sector in which having a government-contractor mandate in effect raised cumulative enrollment (panel B of Table 8). There is no consistent pattern in the estimated coefficients of the unemployment rate

\footnotetext{
${ }^{25}$ Enrollment data by industry are not available for employers with fewer than 5 employees in the DHS data. The QCEW data on the number of establishments used to create the denominators by industry are not available by size category and, therefore, include establishments with fewer than 5 employees. They also only include private-sector employers. There are no QCEW data for the agricultural industry in Washington, DC, so those regressions have 2,350 observations.
} 
and Hispanic immigrant share variables on new enrollment rates across the types of industries (Table 7).

\section{Discussion and Conclusion}

This study is the first to explore DHS data on employer enrollment in the E-Verify system. We find that employer enrollment in E-Verify was higher in states that required some or all employers to use the system. Not surprisingly, universal mandates had a bigger impact on enrollment than public-sector and government-contractor mandates did. While enrolling in EVerify does not necessarily mean that employers use the system, these patterns are similar to earlier results looking at patterns of employer usage (Bachmeier et al. 2012). Enrollment rates tended to be lower in industries with higher concentrations of unauthorized workers, and those industries appear to be less responsive to state E-Verify requirements. Consistent with this finding, earlier research reports that industry E-Verify use is negatively related to industry reliance on unauthorized workers in states with universal mandates (Bachmeier et al. 2012).

The results here indicate that the share of employers enrolled in E-Verify is non-trivial even in states that do not require employers to use it. Employer use of E-Verify in states that do not require its use may complicate analyses of the effects of E-Verify laws that rely on comparisons of states with mandates to those without. The results here also suggest that EVerify's effects are not limited to states with mandates but rather affect workers across the country, albeit to varying degrees. Nonetheless, this study shows that the share of employers enrolled in E-Verify was well below 100 percent in every state. This result suggests that there is substantial scope for a nationwide universal E-Verify requirement, which is frequently proposed during discussions of immigration policy reform, to boost employer usage of the system and 
hence reduce unauthorized immigrants' ability to work in the United States. However, the fact that enrollment rates appeared to plateau at less than 50 percent even in states that had a universal mandate with no size exemptions (Alabama, Arizona, Mississippi, and South Carolina) indicates that a nationwide requirement would need to be accompanied by a substantial enforcement mechanism or other policy changes to be completely effective.

Our results are consistent with employers finding it costly to enroll in and use E-Verify. In particular, our results indicate that employers were more reluctant to sign up when it was harder to find workers (i.e., when labor markets were tight and the unemployment rate was low). Further, employers in industries that relied more on unauthorized workers, such as agriculture, construction, and accommodations and food services, appeared to be more reluctant to sign up than employers in industries where there were few such workers. Our results indicate that large employers were more likely to enroll, perhaps because they were better able to shoulder EVerify's costs, but this pattern implies that small employers would be hurt more by a nationwide mandate.

In sum, the potential benefits of a nationwide E-Verify mandate should be weighed against the costs, which include not only direct costs to employers of using the system but also potentially slower employment growth during economic expansions. Employment and output growth would likely be slower in sectors and areas where unauthorized immigrants are concentrated, at least in the short run. Policy makers concerned about the potential negative economic effects of a nationwide E-Verify requirement might want to combine it with a foreignworker program that brings low-skilled workers in legally or legalizes unauthorized workers who are already here. Doing so would help mitigate any adverse effects on economic growth and 
employment at the time of implementation and give employers and the labor market some time to adjust.

Meanwhile, the benefits of E-Verify requirements are ambiguous. Studies differ in regard to whether US natives and legal immigrants who may be close substitutes for unauthorized immigrant workers saw their labor market opportunities improve in states that enacted E-Verify requirements (Amuedo-Dorantes and Bansak 2014; Bohn et al. 2015; Orrenius and Zavodny 2015). This ambiguity may be partly due to a combination of some employers using E-Verify before states required them to do so, some employers not complying with state requirements, and some employers in other states using E-Verify. These employer adoption patterns make it difficult to assess the E-Verify program's effects by examining state requirements and to accurately forecast the effects of a nationwide requirement. Additional research on employer use of E-Verify and the program's effects on unauthorized immigrants and legal workers is warranted.

In an international context, the US case is quite unique. Employers typically subject unauthorized immigrants' wages to tax withholding, as they do with other workers' earnings. Unauthorized immigrant workers have also historically been eligible for at least some employerprovided benefits. In contrast, employers in most other advanced economies typically do not report employing unauthorized immigrants, keeping them off the firm's payroll and paying them in cash. If the United States moves forward with a nationwide E-Verify mandate, patterns of employment of unauthorized workers will look more like those in Europe and tax evasion and related costs will likely rise. Violations of worker protections, such as minimum wages and safety provisions, may also increase. In addition, unauthorized workers may be more likely to be underrepresented in official data, making government statistics and other surveys less reliable. 


\section{References}

Amuedo-Dorantes, C., and C. Bansak. 2012. "The Labor Market Impact of Mandated Employment Verification Systems." American Economic Review: Papers \& Proceedings 102(3): 543-8. https://doi.org/10.1257/aer.102.3.543

Amuedo-Dorantes, C., and C. Bansak. 2014. "Employment Verification Mandates and the Labor Market Outcomes of Likely Unauthorized and Native Workers." Contemporary Economic Policy 32(3): 671-80. https://doi.org/10.1111/coep.12043

Amuedo-Dorantes, C., and F. Lozano. 2015. "On the Effectiveness of SB1070 in Arizona." Economic Inquiry 53(1): 335-51. https://doi.org/10.1111/ecin.12138

Bachmeier, J., F. Bean, and J. Van Hook. 2012. “Trends in Employers' Usage of E-Verify, 20052009." Unpublished manuscript, Pennsylvania State University.

Bohn, S., and M. Lofstrom. 2013. "Employment Effects of State Legislation.” Pp. 282-314 in Immigration, Poverty, and Socioeconomic Inequality, ed. David Card and Steven Raphael. New York: Russell Sage Foundation.

Bohn, S., M. Lofstrom, and S. Raphael. 2014. "Did the 2007 Legal Arizona Workers Act Reduce the State's Unauthorized Immigrant Population?" Review of Economics and Statistics 96(2): 258-69. https://doi.org/10.1162/rest_a_00429

Bohn, S., M. Lofstrom, and S. Raphael. 2015. "Do E-Verify Mandates Improve Labor Market Outcomes of Low-Skilled Native and Legal Immigrant Workers?" Southern Economic Journal 81(4): 960-79. https://doi.org/10.1002/soej.12019

Boushey, G., and A. Luedtke. 2011. "Immigrants across the U.S. Federal Laboratory: Explaining State-Level Innovation in Immigration Policy." State Politics \& Policy Quarterly 11(4): 390414. https://doi.org/10.1177/1532440011419286

Bruno, A. 2018. "Electronic Employment Eligibility Verification.” Congressional Research Service Report R40446. Washington, DC: Congressional Research Service. https://fas.org/sgp/crs/misc/R40446.pdf.

Good, M. 2013. "Do Immigrant Outflows Lead to Native Inflows? An Empirical Analysis of the Migratory Responses to US State Immigration Legislation.” Applied Economics 45(30): 427597. https://doi.org/10.1080/00036846.2013.786802

Henderson, Tim. 2018. "E-Verify Immigrant Job Screening Is a Game of Chicken, Politics and State Laws." Stateline. Washington, DC: Pew Charitable Trusts. https://www.pewtrusts.org/en/research-and-analysis/blogs/stateline/2018/04/27/job-screeningfor-illegal-immigration-varies-by-state. 
Lichter, D.T., and K.M. Johnson. 2009. "Immigrant Gateways and Hispanic Migration to New Destinations." International Migration Review 43(3): 496-518.

https://doi.org/10.1111/j.1747-7379.2009.00775.x

Monogan III, J. E. 2013. "The Politics of Immigrant Policy in the 50 US States, 2005-2011." Journal of Public Policy 33(I): 35-64. https://doi.org/10.1017/s0143814x12000189

Newman, B. J., C. D. Johnston, A. A. Strickland, and J. Citrin. 2012. “Immigration Crackdown in the American Workplace: Explaining Variation in E-Verify Policy Adoption Across the U.S. States." State Politics \& Policy Quarterly 12(2): 160-82. https://doi.org/10.1177/1532440012442910

Orrenius, P. M., and M. Zavodny. 2015. "The Impact of E-Verify Mandates on Labor Market Outcomes.” Southern Economic Journal 81(4): 947-59. https://doi.org/10.1002/soej.12023

Orrenius, P. M., and M. Zavodny. 2016. "Do State Work Eligibility Verification Laws Reduce Unauthorized Immigration?" IZA Journal of Migration 5(5): 1-17.

https://doi.org/10.1186/s40176-016-0053-3

Orrenius, P. M., and M. Zavodny. 2017. "Digital Enforcement: Effects of E-Verify on Employment and Population of Unauthorized Immigrants." Dallas, TX: Federal Reserve Bank of Dallas.

Passel, J. S., and D. Cohn. 2015. "Share of Unauthorized Immigrant Workers in Production, Construction Jobs Falls since 2007." Washington, DC: Pew Research Center.

http://www.pewhispanic.org/2015/03/26/share-of-unauthorized-immigrant-workers-inproduction-construction-jobs-falls-since-2007/

Pham, H., and P. H. Van. 2014. "Measuring the Climate for Immigrants: A State-by-State Analysis." In Strange Neighbors: The Role of States in Immigration Policy, edited by C. B. Hessick and G. J. Chin, 21-39. New York: New York University Press.

Ybarra, V. D., L. M. Sanchez, and G. R. Sanchez. 2016. “Anti-immigrant Anxieties in State Policy: The Great Recession and Punitive Immigration Policy in the American States, 20052012." State Politics \& Policy Quarterly 16(3): 313-39.

https://doi.org/10.1177/1532440015605815 
Figure 1. States Requiring Some or All Employers to Use E-Verify

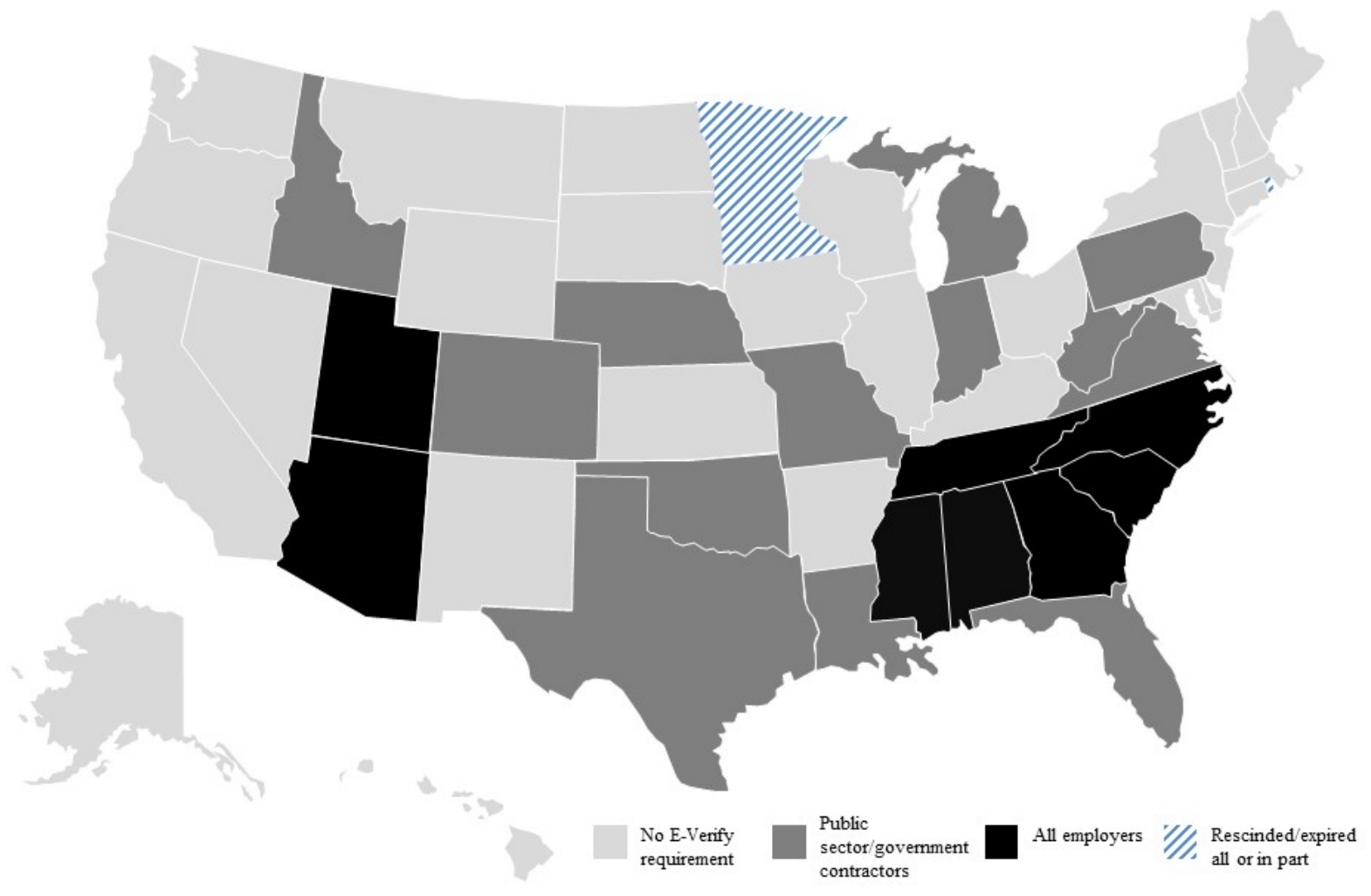

Source: Orrenius and Zavodny (2017). 
Figure 2. Share of Employers in Universal E-Verify States Enrolled in E-Verify, 2004-2015

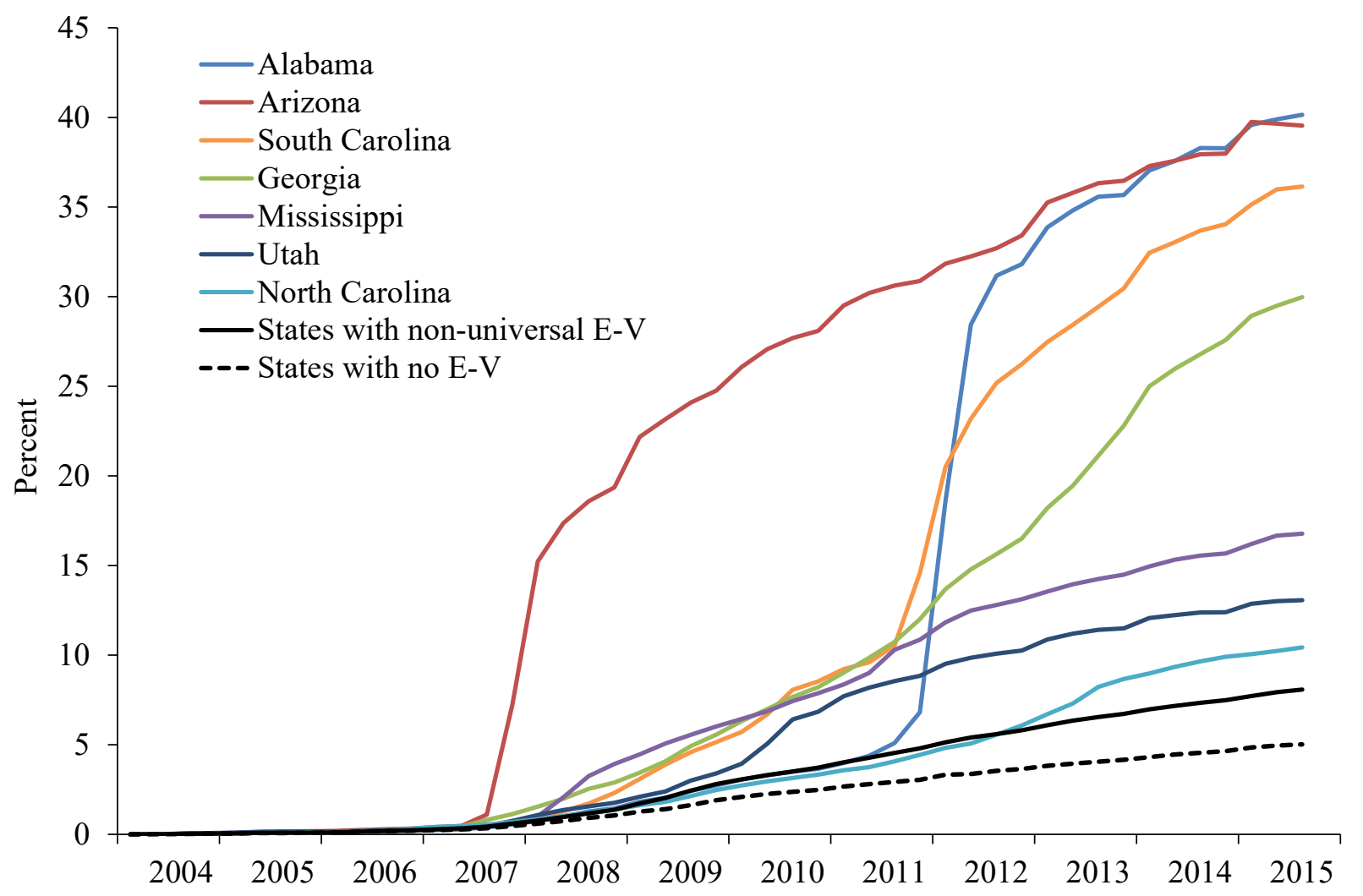

Source: Authors' calculations from DHS data. 
Figure 3. Share of Employers in Non-Universal E-Verify States Enrolled in E-Verify, 2004-2015

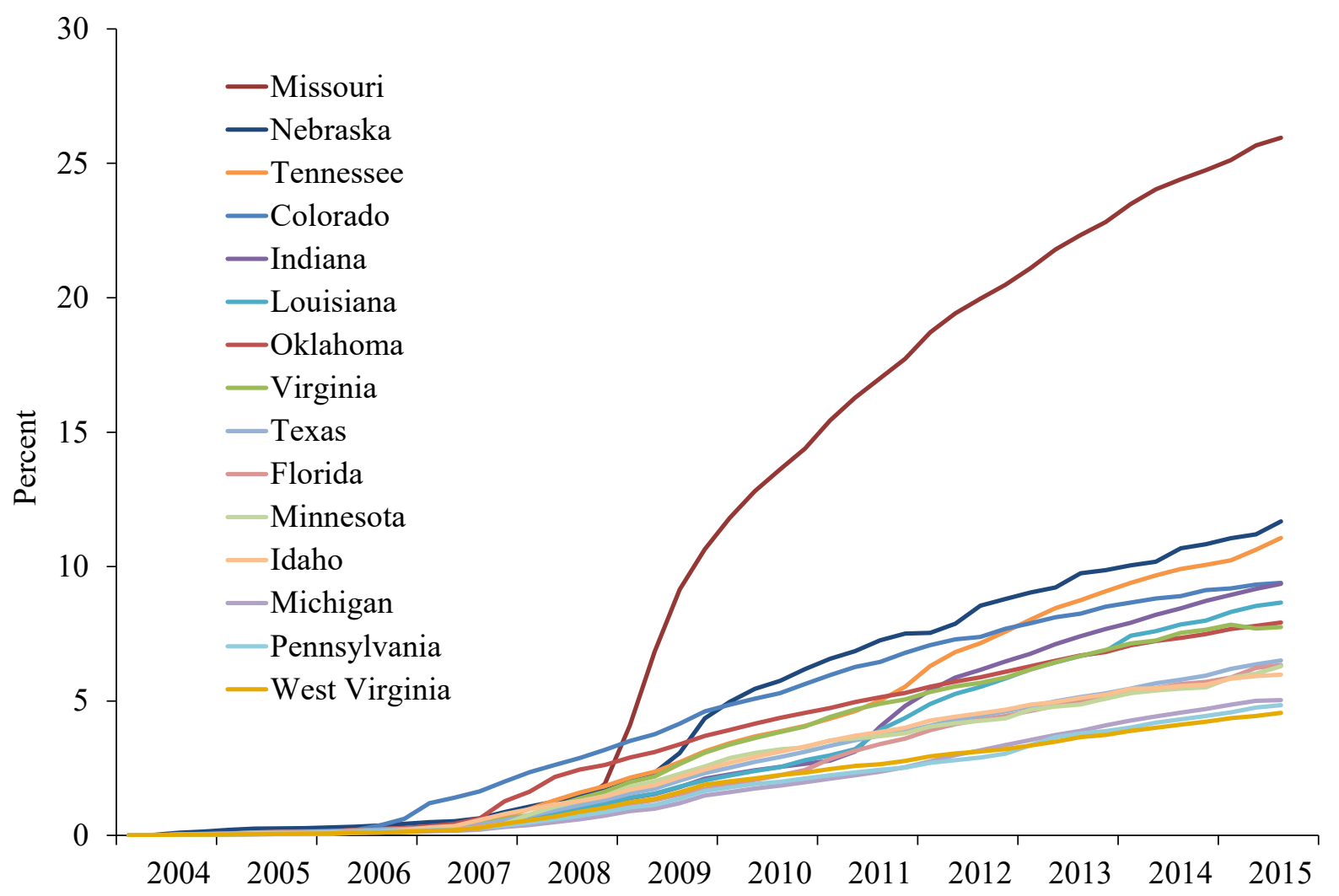

Source: Authors' calculations from DHS data. 
Figure 4. Share of Employers Enrolled in E-Verify by Industry, 2004-2015

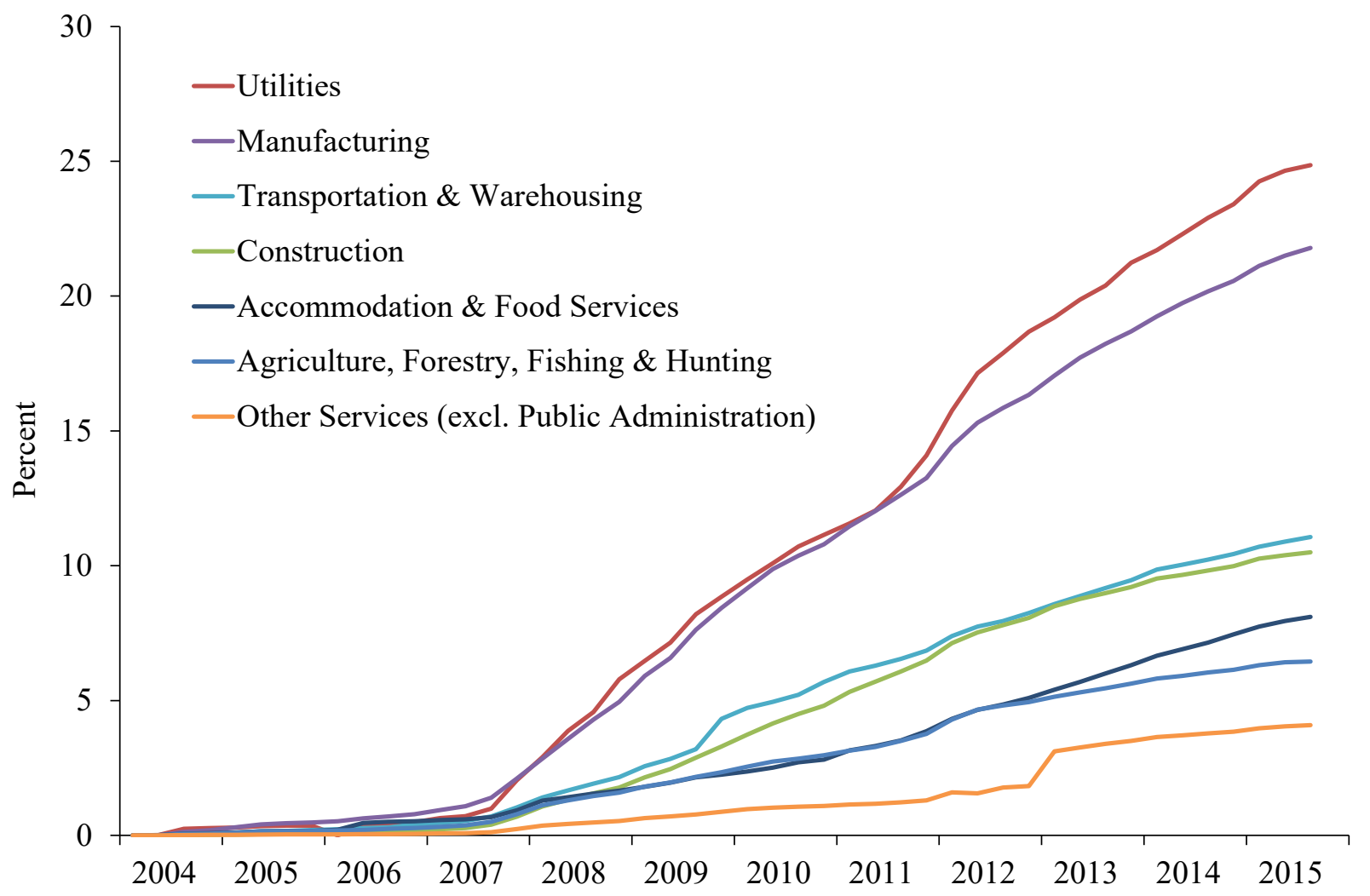

Source: Authors' calculations from DHS data. 
Table 1. Descriptive Statistics.

\begin{tabular}{lccccc}
\hline & & \multicolumn{4}{c}{ Mandate type in effect } \\
\cline { 3 - 5 } & Full sample & All employers & Public sector & Gov’t contractors & None \\
\hline Number of employers newly enrolling & 607 & 1756 & 996 & 949 & 492 \\
Share of employers newly enrolling (\%) & 0.194 & 0.990 & 0.401 & 0.398 & 0.119 \\
Share of employers enrolled (\%) & 3.370 & 21.565 & 6.481 & 6.864 & 1.908 \\
Unemployment rate (\%) & 6.781 & 7.462 & 7.410 & 6.877 & 6.692 \\
Real personal income per capita (\$) & 41,175 & 34,371 & 38,100 & 39,458 & 41,892 \\
Real gov’t expenditures per capita (\$) & 10,454 & 8692 & 8867 & 9194 & 10,754 \\
Housing starts & 47,406 & 25,503 & 35,783 & 31,316 & 50,985 \\
Housing permits & 12,072 & 6487 & 9042 & 7954 & 12,993 \\
Hispanic immigrant pop. share (\%) & 4.260 & 3.458 & 3.345 & 3.338 & 4.458 \\
287(g) agreement & 0.182 & 0.303 & 0.537 & 0.706 & 0.111 \\
Secure Communities & 0.494 & 0.936 & 0.762 & 0.769 & 0.431 \\
Number of observations & 2,397 & 137 & 237 & 259 & 1,953 \\
\hline
\end{tabular}

Notes: Data are state-level quarterly observations for Q1 2004 through Q3 2015. Public sector and government contractor mandates are not mutually exclusive categories. Observations are weighted by the number of establishments in the state and quarter. 
Table 2. Effect of E-Verify Mandates on Number of Employers Newly Enrolling in E-Verify.

\begin{tabular}{lccc}
\hline & $(1)$ & $(2)$ & $(3)$ \\
\hline A. Mandate adopted & $0.987^{* * *}$ & $1.533^{* * *}$ & $1.476^{* * *}$ \\
Mandate for all employers & $(0.243)$ & $(0.165)$ & $(0.144)$ \\
Mandate for public sector & & $0.584^{* * *}$ & $0.338^{* *}$ \\
& & $(0.096)$ & $(0.133)$ \\
Mandate for government contractors & & $0.378^{* *}$ \\
Unemployment rate & & & $(0.173)$ \\
& $0.044^{* *}$ & $0.033^{*}$ & $0.036^{*}$ \\
Hispanic immigrant population share & $(0.021)$ & $(0.019)$ & $(0.019)$ \\
& 0.187 & 0.119 & 0.085 \\
B. Mandate in effect & $(0.127)$ & $(0.109)$ & $(0.107)$ \\
Mandate for all employers & & & \\
& $0.508^{* * *}$ & $0.889^{* * *}$ & $0.829 * * *$ \\
Mandate for public sector & $(0.115)$ & $(0.098)$ & $(0.107)$ \\
& & $0.422^{* * *}$ & 0.128 \\
Mandate for government contractors & & $(0.111)$ & $(0.114)$ \\
& & & $0.501 * *$ \\
Unemployment rate & & & $(0.188)$ \\
& & & $0.044^{* *}$ \\
Hispanic immigrant population share & $0.042^{* *}$ & $0.035^{*}$ & $(0.019)$ \\
& $(0.020)$ & $(0.018)$ & 0.144 \\
Notes: $* \mathrm{p}<0.1 ; * \mathrm{p}<0.05 ; * * * \mathrm{p}<0.01$. Shown are estimated coefficients from OLS
\end{tabular}

regressions with the natural log of the number of employers enrolling in E-Verify in a state and quarter as the dependent variable. Each column is from a separate regression. The regressions also include additional controls for economic conditions, other immigration policies, state and time fixed effects and state-specific linear time trends (see text for details). Observations are weighted using the total number of establishments in a state, and standard errors are clustered on the state. Each regression has 2,397 observations. 
Table 3. Effect of E-Verify Mandates on Share of Employers Newly Enrolling in E-Verify.

\begin{tabular}{|c|c|c|c|}
\hline & $(1)$ & (2) & (3) \\
\hline \multicolumn{4}{|l|}{ A. Mandate adopted } \\
\hline Mandate for all employers & $\begin{array}{l}1.173 * * * \\
(0.381)\end{array}$ & $\begin{array}{l}1.509 * * * \\
(0.004)\end{array}$ & $\begin{array}{l}1.513^{* * *} \\
(0.369)\end{array}$ \\
\hline Mandate for public sector & & $\begin{array}{l}0.359 * * * \\
(0.104)\end{array}$ & $\begin{array}{l}0.377^{* * *} \\
(0.134)\end{array}$ \\
\hline Mandate for government contractors & & & $\begin{array}{l}-0.028 \\
(0.096)\end{array}$ \\
\hline Unemployment rate & $\begin{array}{c}0.046^{*} \\
(0.024)\end{array}$ & $\begin{array}{c}0.039 \\
(0.024)\end{array}$ & $\begin{array}{c}0.039 \\
(0.024)\end{array}$ \\
\hline Hispanic immigrant population share & $\begin{array}{l}0.301 * * \\
(0.146)\end{array}$ & $\begin{array}{c}0.259 * \\
(0.133)\end{array}$ & $\begin{array}{c}0.262 * \\
(0.137)\end{array}$ \\
\hline \multicolumn{4}{|l|}{ B. Mandate in effect } \\
\hline Mandate for all employers & $\begin{array}{l}0.493 * * * \\
(0.124)\end{array}$ & $\begin{array}{l}0.666^{* * *} \\
(0.155)\end{array}$ & $\begin{array}{l}0.628 * * * \\
(0.183)\end{array}$ \\
\hline Mandate for public sector & & $\begin{array}{l}0.191 * * \\
(0.075)\end{array}$ & $\begin{array}{c}0.008 \\
(0.213)\end{array}$ \\
\hline Mandate for government contractors & & & $\begin{array}{c}0.312 \\
(0.307)\end{array}$ \\
\hline Unemployment rate & $\begin{array}{c}0.041 * \\
(0.021)\end{array}$ & $\begin{array}{c}0.038 * \\
(0.021)\end{array}$ & $\begin{array}{c}0.043 * \\
(0.025)\end{array}$ \\
\hline Hispanic immigrant population share & $\begin{array}{c}0.365^{*} \\
(0.202)\end{array}$ & $\begin{array}{c}0.347^{*} \\
(0.199)\end{array}$ & $\begin{array}{c}0.312 \\
(0.194)\end{array}$ \\
\hline \multicolumn{4}{|c|}{$\begin{array}{l}\text { Notes: } * \mathrm{p}<0.1 ; * * \mathrm{p}<0.05 ; * * * \mathrm{p}<0.01 \text {. Shown are estimated coefficients from OLS } \\
\text { regressions with the share of employers enrolling in E-Verify in a state and quarter as the } \\
\text { dependent variable. Each column is from a separate regression. The regressions also include } \\
\text { additional controls for economic conditions, other immigration policies, state and time fixed } \\
\text { effects and state-specific linear time trends (see text for details). Observations are weighted using } \\
\text { the total number of establishments in a state, and standard errors are clustered on the state. Each } \\
\text { regression has } 2,397 \text { observations. }\end{array}$} \\
\hline
\end{tabular}


Table 4. Effect of E-Verify Mandates on Share of Employers Enrolled in E-Verify.

\begin{tabular}{lccc}
\hline & $(1)$ & $(2)$ & $(3)$ \\
\hline A. Mandate adopted & $6.269^{* * *}$ & $6.780^{* * *}$ & $6.742^{* * *}$ \\
Mandate for all employers & $(1.948)$ & $(2.124)$ & $(2.084)$ \\
Mandate for public sector & & 0.546 & 0.380 \\
& & $(0.780)$ & $(1.356)$ \\
Mandate for government contractors & & 0.255 \\
& & & $(1.112)$ \\
B. Mandate in effect & & & \\
Mandate for all employers & $9.135^{* * *}$ & $10.477^{* * *}$ & $10.514^{* * *}$ \\
& $(2.859)$ & $(3.009)$ & $(2.967)$ \\
Mandate for public sector & & 1.485 & 1.665 \\
& & $(0.911)$ & $(1.294)$ \\
Mandate for government contractors & & & -0.308 \\
& & & $(1.011)$ \\
\hline
\end{tabular}

Notes: $* \mathrm{p}<0.1 ; * * \mathrm{p}<0.05 ; * * * \mathrm{p}<0.01$. Shown are estimated coefficients from OLS regressions with the share of employers enrolled in E-Verify in a state and quarter as the dependent variable. Each column is from a separate regression. The regressions also include controls for economic conditions, other immigration policies, state and time fixed effects and state-specific linear time trends (see text for details). Observations are weighted using the total number of establishments in a state, and standard errors are clustered on the state. Each regression has 2,397 observations. 
Table 5. Effect of E-Verify Mandates on Share of Employers Newly Enrolling in E-Verify, by Employer Size.

\begin{tabular}{|c|c|c|c|c|c|}
\hline Employer size & $<5$ employees & 5-19 employees & 20-99 employees & 100-499 employees & $\geq 500$ employees \\
\hline \multicolumn{6}{|l|}{ A. Mandate adopted } \\
\hline Mandate for all employers & $\begin{array}{l}0.790 * * * \\
(0.267)\end{array}$ & $\begin{array}{l}1.908^{* * *} \\
(0.576)\end{array}$ & $\begin{array}{l}3.649 * * * \\
(0.930)\end{array}$ & $\begin{array}{l}6.715^{* * *} \\
(0.863)\end{array}$ & $\begin{array}{l}14.490 * * * \\
(2.113)\end{array}$ \\
\hline Mandate for public sector & $\begin{array}{c}0.190 * \\
(0.100)\end{array}$ & $\begin{array}{l}0.453^{* * *} \\
(0.178)\end{array}$ & $\begin{array}{l}0.873 * * * \\
(0.363)\end{array}$ & $\begin{array}{l}1.983 * * \\
(0.932)\end{array}$ & $\begin{array}{l}6.470 * * \\
(2.622)\end{array}$ \\
\hline Mandate for government contractors & $\begin{array}{l}-0.018 \\
(0.072)\end{array}$ & $\begin{array}{l}-0.074 \\
(0.136)\end{array}$ & $\begin{array}{l}-0.020 \\
(0.275)\end{array}$ & $\begin{array}{c}0.308 \\
(0.831)\end{array}$ & $\begin{array}{c}0.949 \\
(2.156)\end{array}$ \\
\hline Unemployment rate & $\begin{array}{c}0.017 \\
(0.014)\end{array}$ & $\begin{array}{c}0.050 \\
(0.035)\end{array}$ & $\begin{array}{l}0.112 * * \\
(0.054)\end{array}$ & $\begin{array}{l}0.234 * * \\
(0.097)\end{array}$ & $\begin{array}{c}0.468 * \\
(0.240)\end{array}$ \\
\hline Hispanic immigrant population share & $\begin{array}{l}0.112^{* *} \\
(0.045)\end{array}$ & $\begin{array}{c}0.423 * \\
(0.232)\end{array}$ & $\begin{array}{c}0.722 * \\
(0.427)\end{array}$ & $\begin{array}{c}0.876 \\
(0.589)\end{array}$ & $\begin{array}{c}1.215 \\
(1.079)\end{array}$ \\
\hline \multicolumn{6}{|l|}{ B. Mandate in effect } \\
\hline Mandate for all employers & $\begin{array}{l}0.458^{* * * *} \\
(0.124)\end{array}$ & $\begin{array}{l}0.902 * * * \\
(0.329)\end{array}$ & $\begin{array}{l}1.317^{* *} \\
(0.608)\end{array}$ & $\begin{array}{l}-0.006 \\
(1.313)\end{array}$ & $\begin{array}{l}-6.692 * * \\
(2.928)\end{array}$ \\
\hline Mandate for public sector & $\begin{array}{c}0.012 \\
(0.120)\end{array}$ & $\begin{array}{c}0.011 \\
(0.285)\end{array}$ & $\begin{array}{l}-0.033 \\
(0.550)\end{array}$ & $\begin{array}{l}-0.085 \\
(0.999)\end{array}$ & $\begin{array}{l}-1.467 \\
(1.848)\end{array}$ \\
\hline Mandate for government contractors & $\begin{array}{c}0.211 \\
(0.195)\end{array}$ & $\begin{array}{c}0.370 \\
(0.404)\end{array}$ & $\begin{array}{c}0.660 \\
(0.690)\end{array}$ & $\begin{array}{c}1.216 \\
(1.113)\end{array}$ & $\begin{array}{c}4.365^{*} \\
(2.336)\end{array}$ \\
\hline Unemployment rate & $\begin{array}{c}0.021 \\
(0.017)\end{array}$ & $\begin{array}{c}0.058 \\
(0.037)\end{array}$ & $\begin{array}{l}0.122^{* *} \\
(0.052)\end{array}$ & $\begin{array}{l}0.220 * * \\
(0.088)\end{array}$ & $\begin{array}{l}0.426^{* *} \\
(0.207)\end{array}$ \\
\hline Hispanic immigrant population share & $\begin{array}{l}0.127^{* *} \\
(0.062)\end{array}$ & $\begin{array}{c}0.483 \\
(0.306)\end{array}$ & $\begin{array}{c}0.876 \\
(0.589) \\
\end{array}$ & $\begin{array}{c}1.280 \\
(0.955)\end{array}$ & $\begin{array}{c}2.265 \\
(1.878)\end{array}$ \\
\hline
\end{tabular}


Table 6. Effect of E-Verify Mandates on Share of Employers Enrolled in E-Verify, by Employer Size.

\begin{tabular}{|c|c|c|c|c|c|}
\hline Employer size & $<5$ employees & 5-19 employees & 20-99 employees & 100-499 employees & $\geq 500$ employees \\
\hline \multicolumn{6}{|l|}{ A. Mandate adopted } \\
\hline Mandate for all employers & $\begin{array}{l}3.204 * * \\
(1.450)\end{array}$ & $\begin{array}{l}8.692 * * * \\
(3.005)\end{array}$ & $\begin{array}{l}17.512 * * * \\
(5.939)\end{array}$ & $\begin{array}{l}36.881^{* * * *} \\
(8.065)\end{array}$ & $\begin{array}{l}89.149 * * * \\
(17.608)\end{array}$ \\
\hline Mandate for public sector & $\begin{array}{c}0.113 \\
(1.052)\end{array}$ & $\begin{array}{c}0.334 \\
(2.185)\end{array}$ & $\begin{array}{c}1.391 \\
(2.208)\end{array}$ & $\begin{array}{l}6.834 * * \\
(3.354)\end{array}$ & $\begin{array}{l}43.326^{* * *} \\
(12.595)\end{array}$ \\
\hline Mandate for government contractors & $\begin{array}{l}-0.185 \\
(0.843)\end{array}$ & $\begin{array}{c}0.354 \\
(1.872)\end{array}$ & $\begin{array}{c}1.374 \\
(1.434)\end{array}$ & $\begin{array}{c}3.381 \\
(2.265)\end{array}$ & $\begin{array}{c}-2.452 \\
(10.729)\end{array}$ \\
\hline \multicolumn{6}{|l|}{ B. Mandate in effect } \\
\hline Mandate for all employers & $\begin{array}{l}5.771 * * \\
(2.512)\end{array}$ & $\begin{array}{l}13.476^{* * *} \\
(4.182)\end{array}$ & $\begin{array}{l}25.232 * * * \\
(6.137)\end{array}$ & $\begin{array}{l}44.531 * * * \\
(7.761)\end{array}$ & $\begin{array}{l}92.715^{* * *} \\
(17.976)\end{array}$ \\
\hline Mandate for public sector & $\begin{array}{c}1.065 \\
(1.189)\end{array}$ & $\begin{array}{c}1.989 \\
(2.005)\end{array}$ & $\begin{array}{c}3.405^{*} \\
(1.913)\end{array}$ & $\begin{array}{l}9.085^{* *} \\
(4.183)\end{array}$ & $\begin{array}{l}49.568 * * * \\
(12.403)\end{array}$ \\
\hline Mandate for government contractors & $\begin{array}{l}-0.602 \\
(0.875)\end{array}$ & $\begin{array}{l}-0.464 \\
(1.701)\end{array}$ & $\begin{array}{c}0.733 \\
(1.225)\end{array}$ & $\begin{array}{c}3.276 \\
(3.429)\end{array}$ & $\begin{array}{c}-1.137 \\
(10.306)\end{array}$ \\
\hline
\end{tabular}

Notes: $* \mathrm{p}<0.1 ; * \mathrm{p}<0.05 ; * * * \mathrm{p}<0.01$. Shown are estimated coefficients from OLS regressions with the natural log of the number of employers enrolling in E-Verify in a state and quarter as the dependent variable. Each column is from a separate regression. The regressions also include controls for economic conditions, other immigration policies, state and time fixed effects and state-specific linear time trends (see text for details). Observations are weighted using the number of employers in the size class, and standard errors are clustered on the state. Each regression has 2,397 observations. 
Table 7. Effect of E-Verify Mandates on Share of Employers Newly Enrolling in E-Verify, by Industry.

\begin{tabular}{|c|c|c|c|c|c|}
\hline \multirow{2}{*}{$\begin{array}{l}\text { Unauthorized Immigrant Share } \\
\text { Industry }\end{array}$} & \multicolumn{3}{|c|}{ High } & \multirow{2}{*}{$\frac{\text { Medium }}{\text { Manufacturing }}$} & \multirow{2}{*}{$\begin{array}{c}\text { Low } \\
\text { Utilities }\end{array}$} \\
\hline & Agriculture & Construction & Accomm. \& Food & & \\
\hline \multicolumn{6}{|l|}{ A. Mandate adopted } \\
\hline Mandate for all employers & $\begin{array}{l}1.571 * * * \\
(0.571)\end{array}$ & $\begin{array}{l}1.280 * * * \\
(0.449)\end{array}$ & $\begin{array}{l}1.830^{* * *} \\
(0.460)\end{array}$ & $\begin{array}{l}2.091 * * * \\
(0.474)\end{array}$ & $\begin{array}{l}2.665 * * * \\
(0.995)\end{array}$ \\
\hline Mandate for public sector & $\begin{array}{r}0.372 * \\
(0.186)\end{array}$ & $\begin{array}{l}0.390 * * \\
(0.158)\end{array}$ & $\begin{array}{l}0.468 * * \\
(0.195)\end{array}$ & $\begin{array}{l}0.573 * * \\
(0.231)\end{array}$ & $\begin{array}{l}0.986^{* *} \\
(0.444)\end{array}$ \\
\hline Mandate for government contractors & $\begin{array}{l}-0.113 * * \\
(0.133)\end{array}$ & $\begin{array}{c}0.087 \\
(0.110)\end{array}$ & $\begin{array}{l}-0.268 * \\
(0.156)\end{array}$ & $\begin{array}{l}-0.139 \\
(0.188)\end{array}$ & $\begin{array}{c}0.185 \\
(0.333)\end{array}$ \\
\hline Unemployment rate & $\begin{array}{c}0.043 \\
(0.031)\end{array}$ & $\begin{array}{l}0.049 * * \\
(0.024)\end{array}$ & $\begin{array}{c}0.028 \\
(0.024)\end{array}$ & $\begin{array}{c}0.066^{*} \\
(0.034)\end{array}$ & $\begin{array}{c}0.165 * \\
(0.096)\end{array}$ \\
\hline Hispanic immigrant population share & $\begin{array}{c}0.426^{*} \\
(0.245)\end{array}$ & $\begin{array}{c}0.406^{*} \\
(0.202)\end{array}$ & $\begin{array}{c}0.367 \\
(0.233)\end{array}$ & $\begin{array}{c}0.437 * \\
(0.254)\end{array}$ & $\begin{array}{l}0.652^{* *} \\
(0.312)\end{array}$ \\
\hline \multicolumn{6}{|l|}{ B. Mandate in effect } \\
\hline Mandate for all employers & $\begin{array}{c}0.626^{*} \\
(0.315)\end{array}$ & $\begin{array}{c}0.309 \\
(0.247)\end{array}$ & $\begin{array}{l}0.992 * * * \\
(0.283)\end{array}$ & $\begin{array}{c}0.639 * \\
(0.321)\end{array}$ & $\begin{array}{l}-0.276 \\
(0.532)\end{array}$ \\
\hline Mandate for public sector & $\begin{array}{l}-0.111 \\
(0.300)\end{array}$ & $\begin{array}{c}0.014 \\
(0.190)\end{array}$ & $\begin{array}{c}0.172 \\
(0.225)\end{array}$ & $\begin{array}{l}-0.027 \\
(0.293)\end{array}$ & $\begin{array}{l}-0.432 \\
(0.814)\end{array}$ \\
\hline Mandate for government contractors & $\begin{array}{c}0.418 \\
(0.429)\end{array}$ & $\begin{array}{c}0.439 * \\
(0.234)\end{array}$ & $\begin{array}{l}-0.055 \\
(0.276)\end{array}$ & $\begin{array}{c}0.302 \\
(0.385)\end{array}$ & $\begin{array}{c}1.714 \\
(1.214)\end{array}$ \\
\hline Unemployment rate & $\begin{array}{c}0.051 \\
(0.032)\end{array}$ & $\begin{array}{l}0.052 * * \\
(0.021)\end{array}$ & $\begin{array}{c}0.032 \\
(0.024)\end{array}$ & $\begin{array}{l}0.073 * * \\
(0.033)\end{array}$ & $\begin{array}{l}0.178^{* *} \\
(0.087)\end{array}$ \\
\hline Hispanic immigrant population share & $\begin{array}{c}0.468 \\
(0.299)\end{array}$ & $\begin{array}{c}0.447 \\
(0.279)\end{array}$ & $\begin{array}{c}0.454 \\
(0.304)\end{array}$ & $\begin{array}{c}0.520 \\
(0.348)\end{array}$ & $\begin{array}{c}0.632 \\
(0.388)\end{array}$ \\
\hline
\end{tabular}

Notes: $* \mathrm{p}<0.1 ; * * \mathrm{p}<0.05 ; * * * \mathrm{p}<0.01$. Shown are estimated coefficients from OLS regressions with the share of employers enrolling in E-Verify in a state and quarter as the dependent variable. Each column is from a separate regression. The regressions also include additional controls for economic conditions, other immigration policies, state and time fixed effects and state-specific linear 
time trends (see text for details). Observations are weighted using the number of employers in the industry, and standard errors are clustered on the state. 
Table 8. Effect of E-Verify Mandates on Share of Employers Enrolled in E-Verify, by Industry.

\begin{tabular}{|c|c|c|c|c|c|}
\hline \multirow{2}{*}{$\begin{array}{l}\text { Unauthorized Immigrant Share } \\
\text { Industry }\end{array}$} & \multicolumn{3}{|c|}{ High } & \multirow{2}{*}{$\frac{\text { Medium }}{\text { Manufacturing }}$} & \multirow{2}{*}{$\begin{array}{c}\text { Low } \\
\text { Utilities }\end{array}$} \\
\hline & Agriculture & Construction & Accomm. \& Food & & \\
\hline \multicolumn{6}{|l|}{ A. Mandate adopted } \\
\hline Mandate for all employers & $\begin{array}{l}7.224^{* *} \\
(3.185)\end{array}$ & $\begin{array}{l}7.044^{* * *} \\
(1.741)\end{array}$ & $\begin{array}{l}7.207 * * \\
(2.866)\end{array}$ & $\begin{array}{l}9.663^{* * *} \\
(3.033)\end{array}$ & $\begin{array}{l}16.674 * * * \\
(5.073)\end{array}$ \\
\hline Mandate for public sector & $\begin{array}{c}0.686 \\
(1.980)\end{array}$ & $\begin{array}{c}1.058 \\
(0.943)\end{array}$ & $\begin{array}{l}-0.833 \\
(1.700)\end{array}$ & $\begin{array}{c}1.156 \\
(1.120)\end{array}$ & $\begin{array}{c}1.953 \\
(2.236)\end{array}$ \\
\hline Mandate for government contractors & $\begin{array}{l}-0.075 \\
(1.655)\end{array}$ & $\begin{array}{l}-0.330 \\
(0.896)\end{array}$ & $\begin{array}{c}1.112 \\
(1.436)\end{array}$ & $\begin{array}{l}-0.208 \\
(0.719)\end{array}$ & $\begin{array}{c}1.633 \\
(1.435)\end{array}$ \\
\hline \multicolumn{6}{|l|}{ B. Mandate in effect } \\
\hline Mandate for all employers & $\begin{array}{l}11.321 * * \\
(4.430)\end{array}$ & $\begin{array}{l}9.535^{* * *} \\
(2.315)\end{array}$ & $\begin{array}{l}12.128^{* * *} \\
(3.163)\end{array}$ & $\begin{array}{l}13.944^{* * *} \\
(3.276)\end{array}$ & $\begin{array}{l}21.889 * * * \\
(7.406)\end{array}$ \\
\hline Mandate for public sector & $\begin{array}{c}1.964 \\
(1.927)\end{array}$ & $\begin{array}{l}1.974 * * \\
(0.874)\end{array}$ & $\begin{array}{c}0.932 \\
(1.284)\end{array}$ & $\begin{array}{l}2.226^{* *} \\
(1.066)\end{array}$ & $\begin{array}{l}4.663 * * \\
(2.136)\end{array}$ \\
\hline Mandate for government contractors & $\begin{array}{l}-0.801 \\
(1.490)\end{array}$ & $\begin{array}{l}-0.078 \\
(0.711)\end{array}$ & $\begin{array}{l}-0.347 \\
(1.101)\end{array}$ & $\begin{array}{l}-0.665 \\
(0.722)\end{array}$ & $\begin{array}{l}2.159 * * \\
(1.069)\end{array}$ \\
\hline
\end{tabular}

Notes: $* \mathrm{p}<0.1 ; * * \mathrm{p}<0.05 ; * * * \mathrm{p}<0.01$. Shown are estimated coefficients from OLS regressions with the share of employers enrolling in E-Verify in a state and quarter as the dependent variable. Each column is from a separate regression. The regressions also include additional controls for economic conditions, other immigration policies, state and time fixed effects and state-specific linear time trends (see text for details). Observations are weighted using the number of employers in the industry, and standard errors are clustered on the state. 


\section{Appendix: Share of Employers Enrolled in E-Verity by State and E-Verify Laws, 2004-}

2015.

A solid vertical line indicates implementation of a universal requirements, and a dashed vertical line indicates implementation of a public sector or government contractor requirement. Only the first law of a given type is indicated. The data are quarterly for the first quarter of 2004 through the third quarter of 2015.
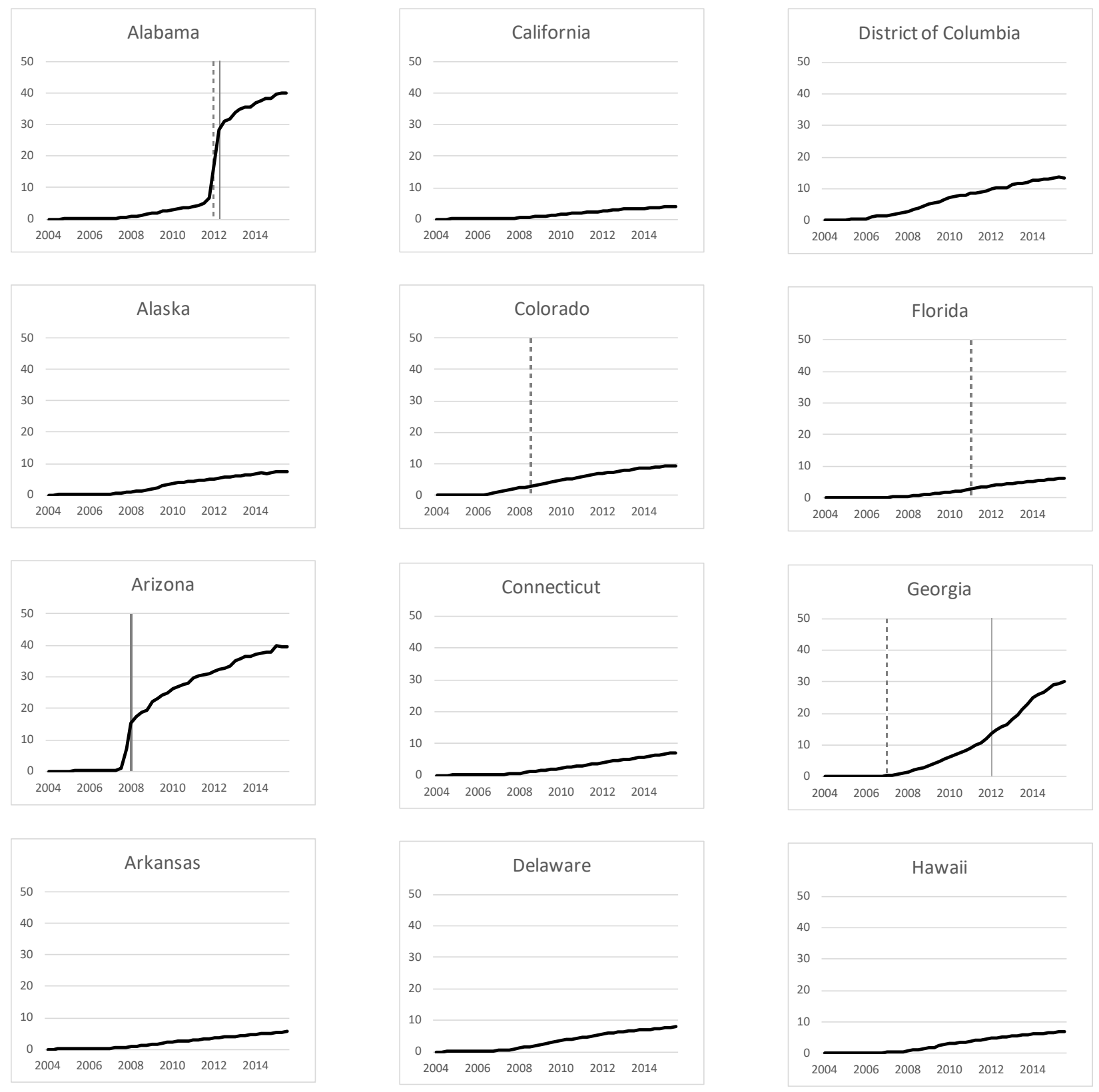

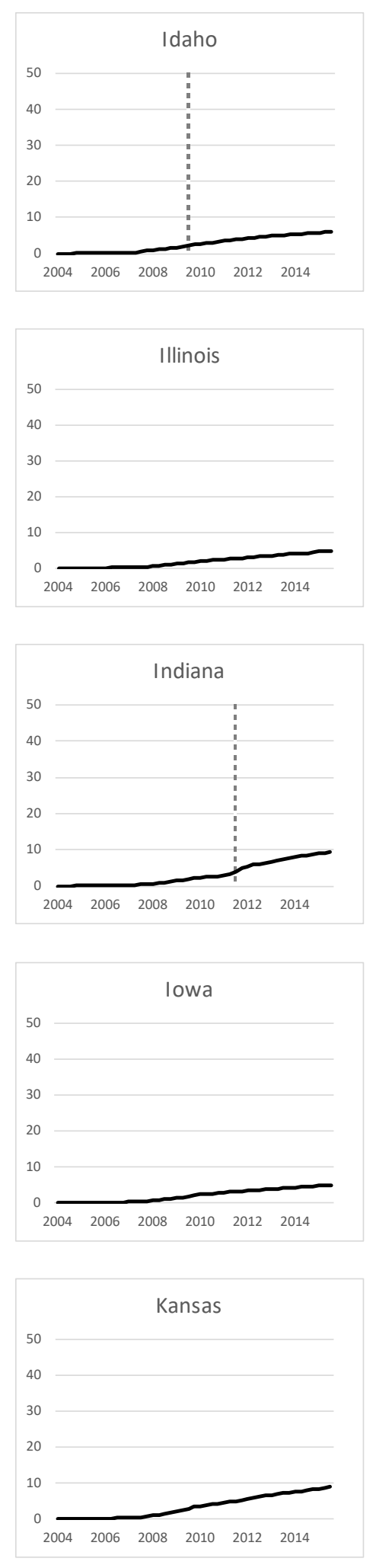
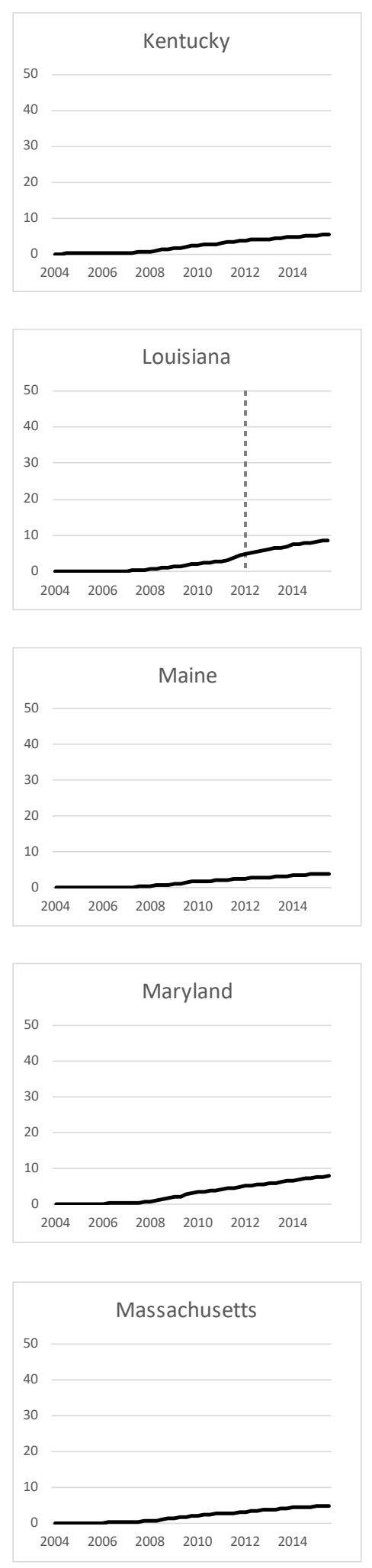
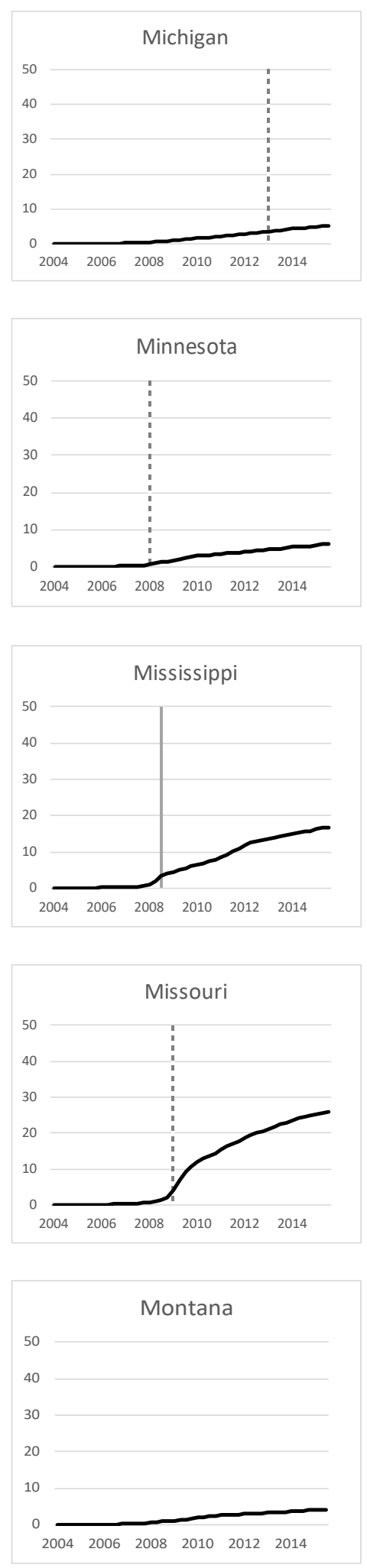

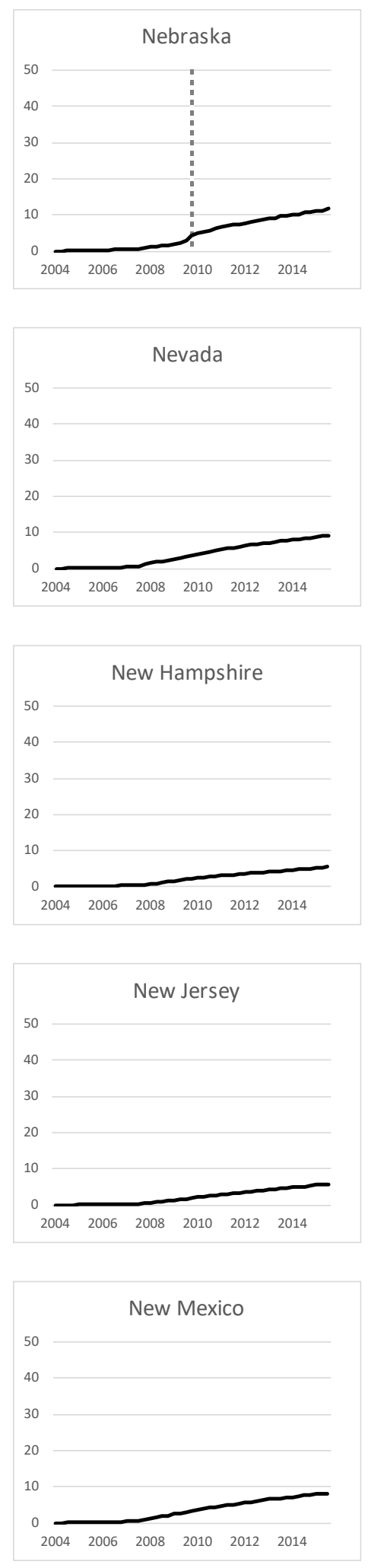
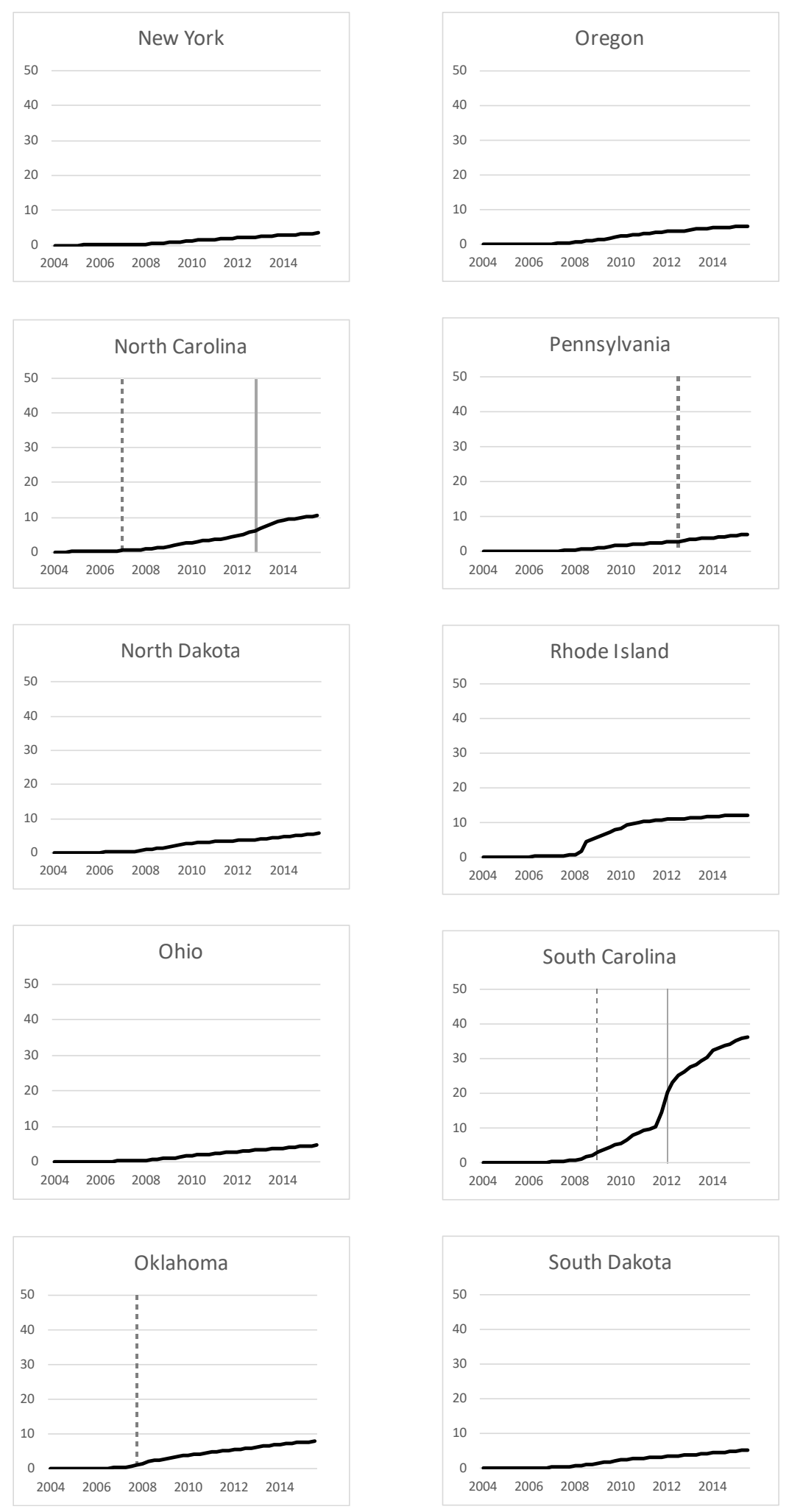

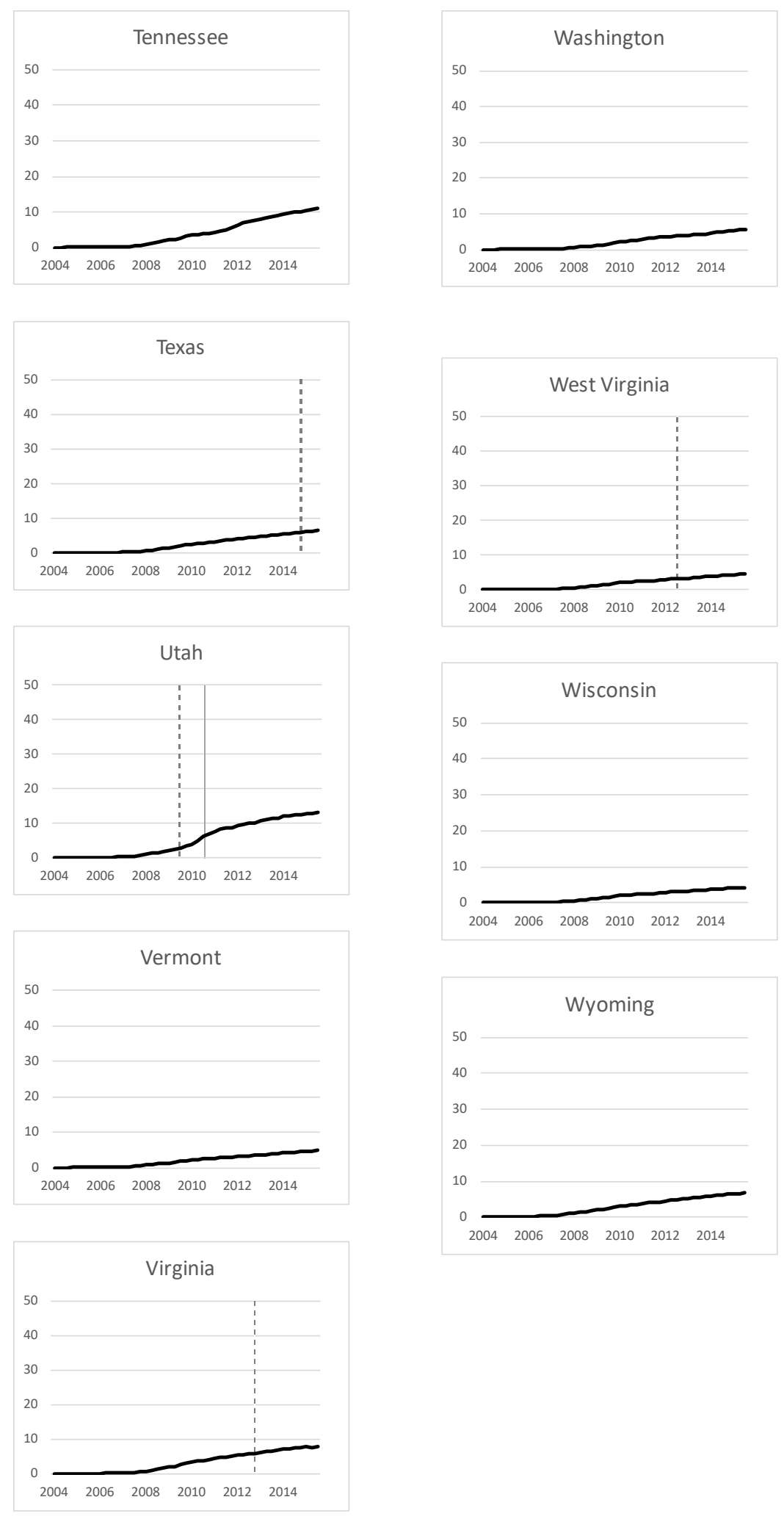